U.S. Department of the Interior

U.S. Geological Survey

\title{
Hydrology and Water Quality of the Grand Portage Reservation, Northeastern Minnesota, 1991-2000
}

By T.A. Winterstein

Water-Resources Investigations Report 02-4156

Prepared in cooperation with the Grand Portage Band of Chippewa 


\title{
U.S. DEPARTMENT OF THE INTERIOR
}

\author{
Gale A. Norton, Secretary
}

\section{U.S. GEOLOGICAL SURVEY}

Charles G. Groat, Director

Use of trade, product or firm names in this report is for identification purposes only and does not constitute endorsement by the U.S. Geological Survey.

Mound View, Minnesota, 2002

For additional information write to:

\section{U.S. Geological Survey}

District Chief

2280 Woodale Drive

Mounds View, MN 55112

Copies of this report can be purchased from:

\section{U.S. Geological Survey}

Branch of Information Services

Box 25286, MS 517

Federal Center

Denver, CO 80225

Information regarding the USGS is available on the Internet via the World Wide Web.

You may connect to the USGS Home Page using the Universal Resource Locator (URL) at http://www.rvares.er.usgs.gov

You may also connect to the Minnesota District Home Page at http://mn.water.usgs.gov/

For more information on all USGS reports and products (including maps, images, and computerized data), call 1-888-ASK-USGS

Water-Resources Investigations Report 02-4156 


\section{CONTENTS}

Abstract

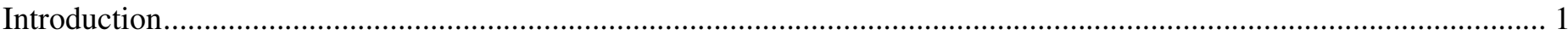

Purpose and scope

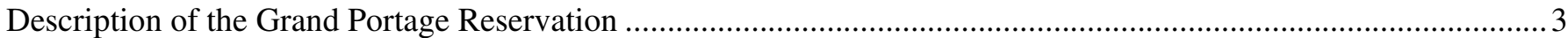

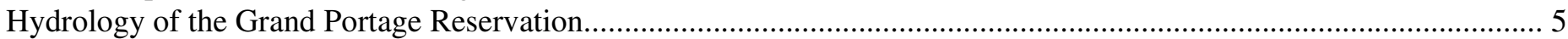

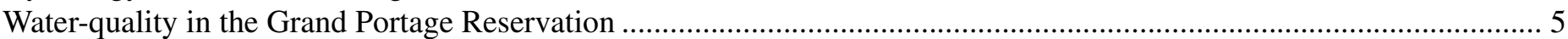

Determining the recharge age of water from the Grand Portage Reservation ......................................................... 15

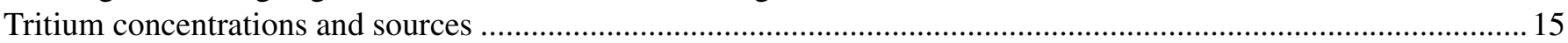

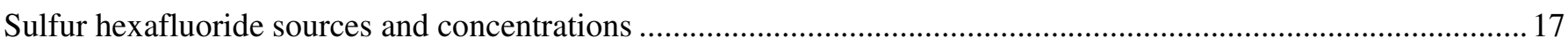

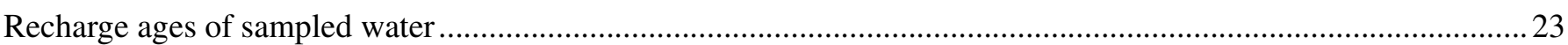

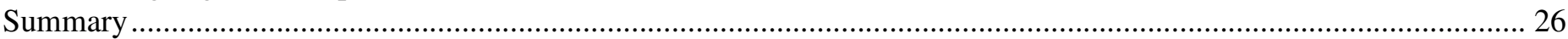

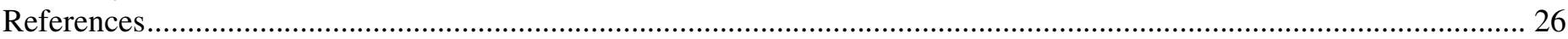

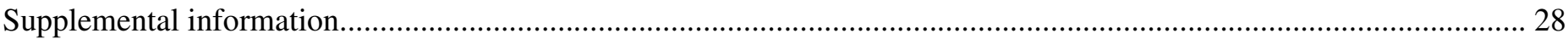

\section{ILLUSTRATIONS}

Figures 1-3. Maps showing:

1. Location of the study area, Grand Portage Reservation, Minnesota ….........................................................2

2. Bedrock geology of the Grand Portage Reservation, Minnesota ….............................................................

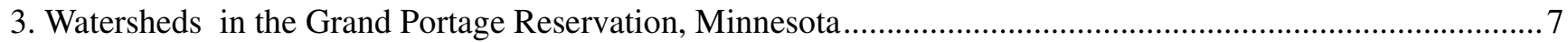

Figures 4-8. Graphs showing:

4. Discharge and runoff from Reservation River, and Grand Portage Creek, Grand Portage Reservation,

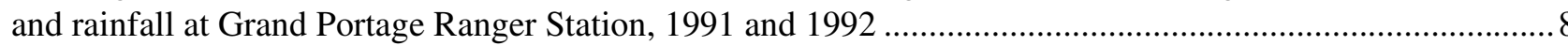

5. Daily precipitation at Grand Portage Ranger Station, cumulative departure from the mean of daily rainfall, and lake stages of Loon and Cuffs Lakes, Grand Portage Reservation, Minnesota, March 1998

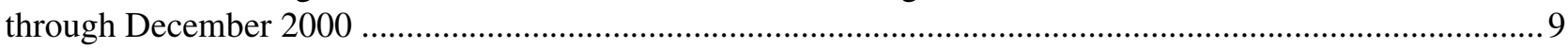

6. Concentrations of cations and anions in water sampled from wells in the Grand Portage Reservation,

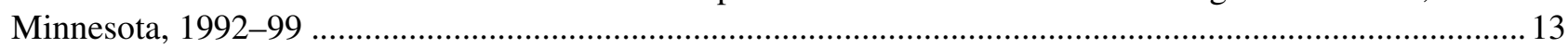

7. Concentrations of cations and anions in water sampled from springs in the Grand Portage Reservation,

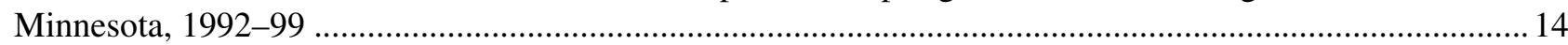

8. Concentration of cations and anions in water sampled from lakes and streams in the Grand Portage

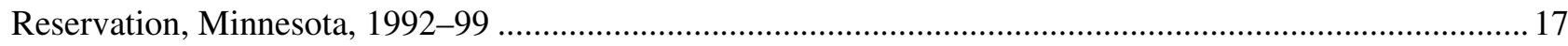

Figure 9. Trilinear diagran showing percentage distribution of major ion concentrations in water samples from ground water, springs, lakes, and streams in the Grand Portage Reservation, Minnesota, 1992-99

Figures 10-11. Graphs showing:

10. Temperature and dissolved oxygen profiles for Taylor and Center Lakes, Grand Portage Reservation, Minnesota, 1999-2000

11. Tritium concentrations in wells and springs and estimated recharge age of water in one well and two springs by sulfur hexafluoride dating in the Grand Portage Reservation, Minnesota, August 1999

\section{TABLES}

Table 1. Wells, springs, streams and lakes sampled in the Grand Portage Reservation, Minnesota, 1992-2001

Table 2. Ranges of $\mathrm{pH}$, alkalinity, specific conductance, and ionic concentrations of water sampled in the Grand Portage Reservation, Minnesota, 1992-99

Table 3. Hydrogeologic characteristics and well data for selected wells in the Grand Portage Reservation,

Minnesota, 1992-2000.

Table 4. Field measurements at seven lakes in Grand Portage Reservation, Minnesota, 1997-2000 .............................20

Table 5. U.S. Environmental Protection Agency drinking-water standards and health advisories ................................23

Table 6. Tritium data collected from wells and springs in the Grand Portage Reservation, Minnesota, August 16-24, 1999 


\section{TABLES-CONTINUED}

Table 7. Estimated recharge age of water by sulfur hexafluoride analysis in wells and springs in the Grand Portage

Reservation, Minnesota, sampled August and October 2000 25

Table S-1. Water-quality data collected from wells in the Grand Portage Reservation, Minnesota, August 1999 ............30

Table S-2. Water-quality data collected from springs in the Grand Portage Reservation, Minnesota, 1999....................32

Table S-3. Quality-assurance samples from the Grand Portage Reservation, Minnesota, August 1999 ..........................34

Table S-4. Percent difference between concentrations in field samples and replicate samples from well GW-4,

Grand Portage Reservation, Minnesota, August 16, 1999 35

\section{CONVERSION FACTORS}

Multiply

inch (in.)

Foot (ft)

Mile

Square foot per day $\left(\mathrm{ft}^{2} / \mathrm{d}\right)$

Square mile $\left(\mathrm{mi}^{2}\right)$

Gallon per minute ( $\mathrm{gal} / \mathrm{min}$ )

Degrees Fahrenheit $\left({ }^{\circ} \mathrm{F}\right)$
By

2.54

0.3048

1.609

0.09290

2.590

$6.390 \times 10^{-5}$

(temperature ${ }^{\circ} \mathrm{F}-32$ )/1.8
To obtain

centimeter

meter

kilometer

square meter per day square kilometer $\left(\mathrm{km}^{2}\right)$ cubic meter per second degrees Celsius $\left({ }^{\circ} \mathrm{C}\right)$

Chemical concentrations are given in metric units. Chemical concentrations of substances in water are given in milligrams per liter (mg/L) or micrograms per liter (ug/L). Milligrams per liter are a unit expressing the concentration of chemical constituents in solution as mass (milligrams) of solute per unit volume (liter) of water. Micrograms per liter is a unit expressing the concentration of chemical constituents in solution as mass (micrograms) of solute per unit volume (liter) of water. One thousand micrograms per liter is equivalent to one milligram per liter. 


\section{Hydrology and Water Quality of the Grand Portage Reservation, Northeastern Minnesota, 1991-2000}

\section{by T.A. Winterstein}

\section{ABSTRACT}

The Grand Portage Reservation is located in northeastern Cook County, Minnesota at the boundary between Minnesota, USA, and Ontario, Canada. Between 1991 and 2000 the U.S. Geological Survey conducted a series of studies, with the cooperation with Grand Portage Band of Chippewa, to describe the water resources of the Grand Portage Reservation.

Ground water moves primarily through fractures in the bedrock, probably in three ground-water systems: local, regional, and deep. Lake Superior is thought to be the discharge point for brines in the deep ground-water flow system.

The watersheds in the Grand Portage Reservation are small and steep; consequently streams in the Grand Portage Reservation tend to be flashy. Lake stages rise and fall with rainfall.

The $\mathrm{pH}$ of water in the Reservation is generally alkaline ( $\mathrm{pH}$ greater than 7.0). The alkalinity of water in the Reservation is low. Concentrations of major ions are much greater in ground water than in spring water and surface water.

The ionic composition of water in the Reservation differs depending upon the source of the water. Water from 11 of the 20 wells sampled are a calcium-sodium-chloride type. Water from wells GW-2, GW-7, and GW-11 had much greater specific conductance concentrations of major ions compared to the other wells. Some spring water (SP-1, SP-3, SP-4, SP-6, and SP-8) is calcium-bicarbonate type like surface water, whereas other spring water (SP-5 and SP-7) is similar to the calcium-sodium-chloride type occurring in samples from about one-half the wells. The major chemical constituents in surface water are bicarbonate, calcium, and magnesium.

Measured tritium and sulfur hexafluoride $\left(\mathrm{SF}_{6}\right)$ concentrations in water samples from springs and wells were used to determine the recharge age of the sampled water. The recharge ages of two of the wells sampled for tritium are before 1953. The recharge ages of the remaining 10 samples for tritium are probably after 1970. The recharge ages of seven $\mathrm{SF}_{6}$ samples were between 1973 and 1998.

\section{INTRODUCTION}

The Grand Portage Reservation is located in northeastern Cook County, Minnesota at the boundary between Minnesota, USA and Ontario, Canada (fig. 1). The Reservation is about 88 $\mathrm{mi}^{2}$ in area and located within the Northern Lakes and Forests Ecoregion (Omernick, 1987), which contains numerous hills, small valleys, streams, lakes, and wetlands. Although some areas of the Reservation have been recently logged and logging continues, the majority of the forest is second growth forest and undisturbed (the entire area was logged during the late 1800's and early 1900's). Most homes, businesses, and tourist and historical attractions are located in the community of Grand Portage, along Highway 61, and along Highway 17 east of Mineral Center.

During 1991-2000, the U.S. Geological Survey (USGS) conducted a series of studies, in cooperation with Grand Portage Band of Chippewa, to describe the water resources of the Grand Portage Reservation (Ruhl, 1995 and 1997; Winterstein, 2000). The purpose of these studies was to provide the Reservation Tribal Council (1) information about the ground water beneath the Reservation that would help the Council in the efficient development of ground-water supplies for commercial and residential use, (2) water-quality information about Grand Portage and Wauswaugoning Bays, which have important aesthetic, fishery, and 


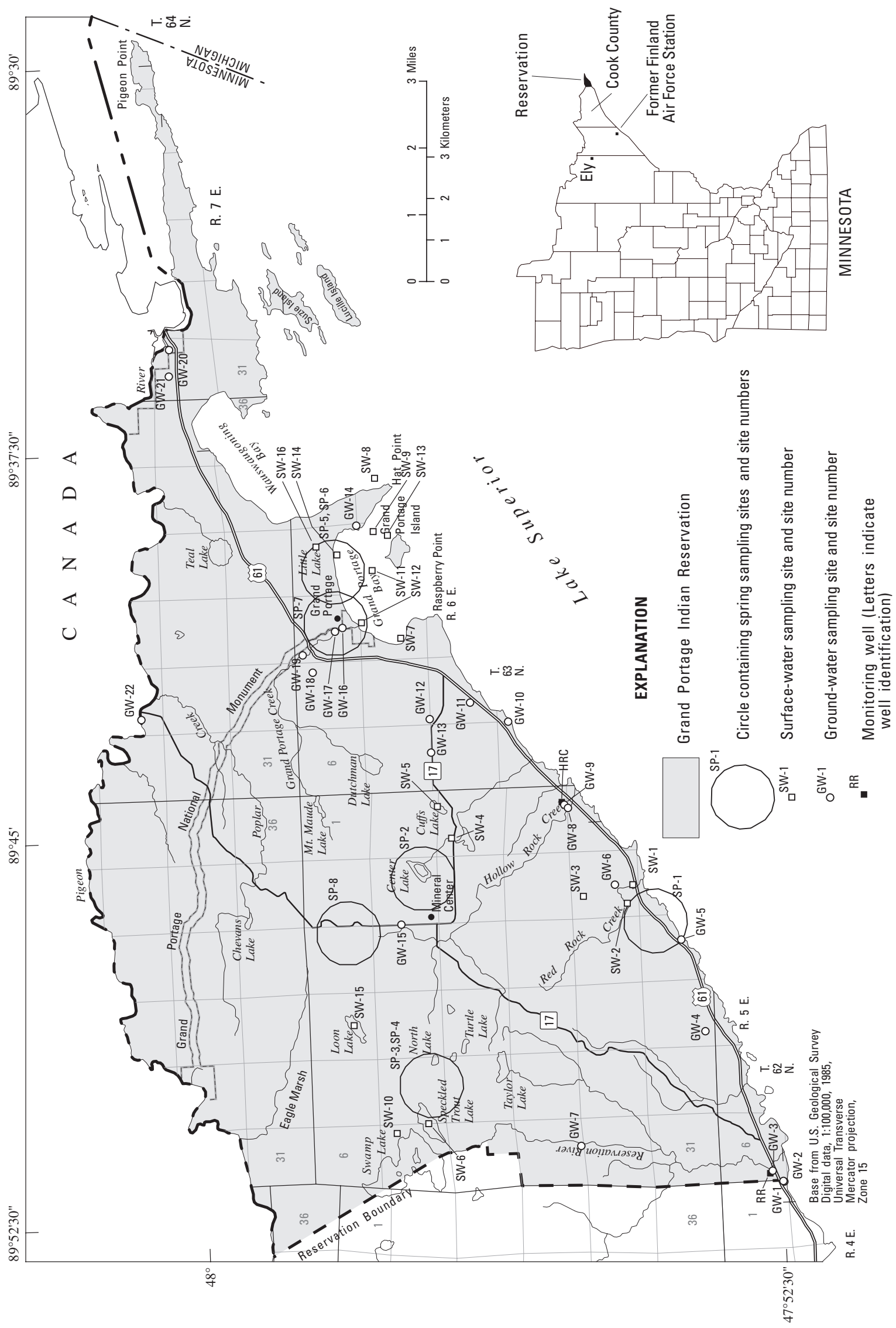

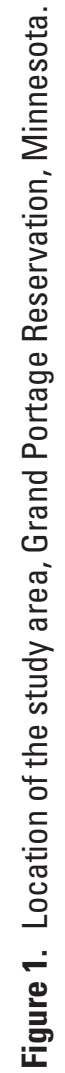


water-supply values to the Reservation, and (3) to collect the data needed to improve our knowledge of the source and water-quality of ground water beneath the Reservation, to manage the flow and protect the water quality of several streams in the Reservation, and to protect the water quality of lakes and wetlands within the Reservation.

The three reports that have been written as a result of the studies (Ruhl, 1995 and 1997; Winterstein, 2000) contain information about (1) streamflow characteristics of Reservation River, Grand Portage Creek, and Pigeon River; (2) estimated transmissivities of aquifers beneath the Reservation; (3) well yields and the effects of hydrofracturing on well yields; (4) general physical and chemical properties of ground water from 10 wells within the Reservation; (5) general physical and chemical properties of water and bottom sediment collected from Grand Portage and Wauswaugoning Bays of Lake Superior; (6) general physical and chemical properties of water collected from two streams, two wetlands, and four lakes within the Reservation; and (7) analyses of trace metals and selected organic constituents in lake sediments from two lakes. Water quality and recharge-age data that was collected during 1999-2000 from wells and springs in the Reservation has not been published.

Although parts of the hydrology of the Grand Portage Reservation have been described in the three reports, the hydrology of the surface and ground waters of the entire Reservation has not been described. The water quality of ground water has not been compared to the water quality of surface waters, and the water-quality data collected since 1997 has not been compared to the water-quality data collected during 1991-1996.

\section{PURPOSE AND SCOPE}

The purpose of this report is to: (1) describe the ground- and surfacewater hydrology of the entire Reservation; (2) describe the water-quality of lakes, streams, springs, and wells in the Reservation using the data collected during 1991-2000; and (3) present the results of ground-water recharge-age dating using tritium and sulfur hexafluoride data collected during 1999-2000. Data collected during 1999-2000 and the methods used to collect it are presented in the Supplemental Information Section.

\section{DESCRIPTION OF THE GRAND PORTAGE RESERVATION}

The climate of the Grand Portage Reservation is continental. Average monthly temperature ranges from about $8^{\circ} \mathrm{F}$ during January to about $62^{\circ} \mathrm{F}$ during July (Baker and others, 1985). Average annual precipitation is about 29 in. based on a period of record from 1941 to 1970 (Baker and Kuehnast, 1978). About two-thirds of precipitation is rain during April through November. The other onethird is snowfall during December through March.

The hydrology of the Grand Portage Reservation is greatly influenced by the geology of the Reservation (fig. 2). In the Grand Portage Reservation, Early to Middle Proterozoic bedrock is covered by thin glacial deposits of Pleistocene age. The oldest rocks are the Early Proterozoic Rove Formation of the Animikie Group, nearly flat-lying argillites, slates, and greywackes. The Rove Formation covers most of the northern part of the Reservation and is truncated in the south by younger rocks of the Middle Proterozoic Keweenawan Supergroup (Green, 1982). The earli- est Middle Proterozoic rocks are clastic sandstone of the Punkwunge Formation that crop out along a narrow east-west strip through the center of the Reservation. Overlying the Punkwunge Formation and covering much of the southwestern one-half of the Reservation are igneous rocks of the North Shore Volcanic Group. Rocks of the North Shore Volcanic Group include the Grand Portage lavas, the Hovland lavas and the Brule/Hovland-Reservation River diabase (Green, 1982; and Laurel Woodruff, U.S. Geological Survey, personal commun., 2002). All rock units in the Reservation are cut by several generations of Middle Proterozoic diabase dikes. The dikes have variable strikes, including east-west, northeast-southwest, and northwestsoutheast, and may represent a single intrusion or may be more complex multiple intrusions, such as the dike that forms Hat Point.

Bedrock structure controlled the formation of the major slopes, ridges, and valleys. Glaciation, weathering, stream erosion, and wave action of Lake Superior have resulted in the formation and deposition of unconsolidated materials on top of the bedrock (Ruhl, 1995). The unconsolidated materials consist mainly of glacial deposits, but include post-glacial alluvium, beach deposits, and peat. The thickness of the unconsolidated materials generally is less than $50 \mathrm{ft}$, but can be as great as $100 \mathrm{ft}$.

The land surface of the Grand Portage Reservation rises from Lake Superior to highlands in the center of the Reservation and then declines to the Pigeon River, the northern boundary of the Reservation. The highest elevation in the Reservation is near 


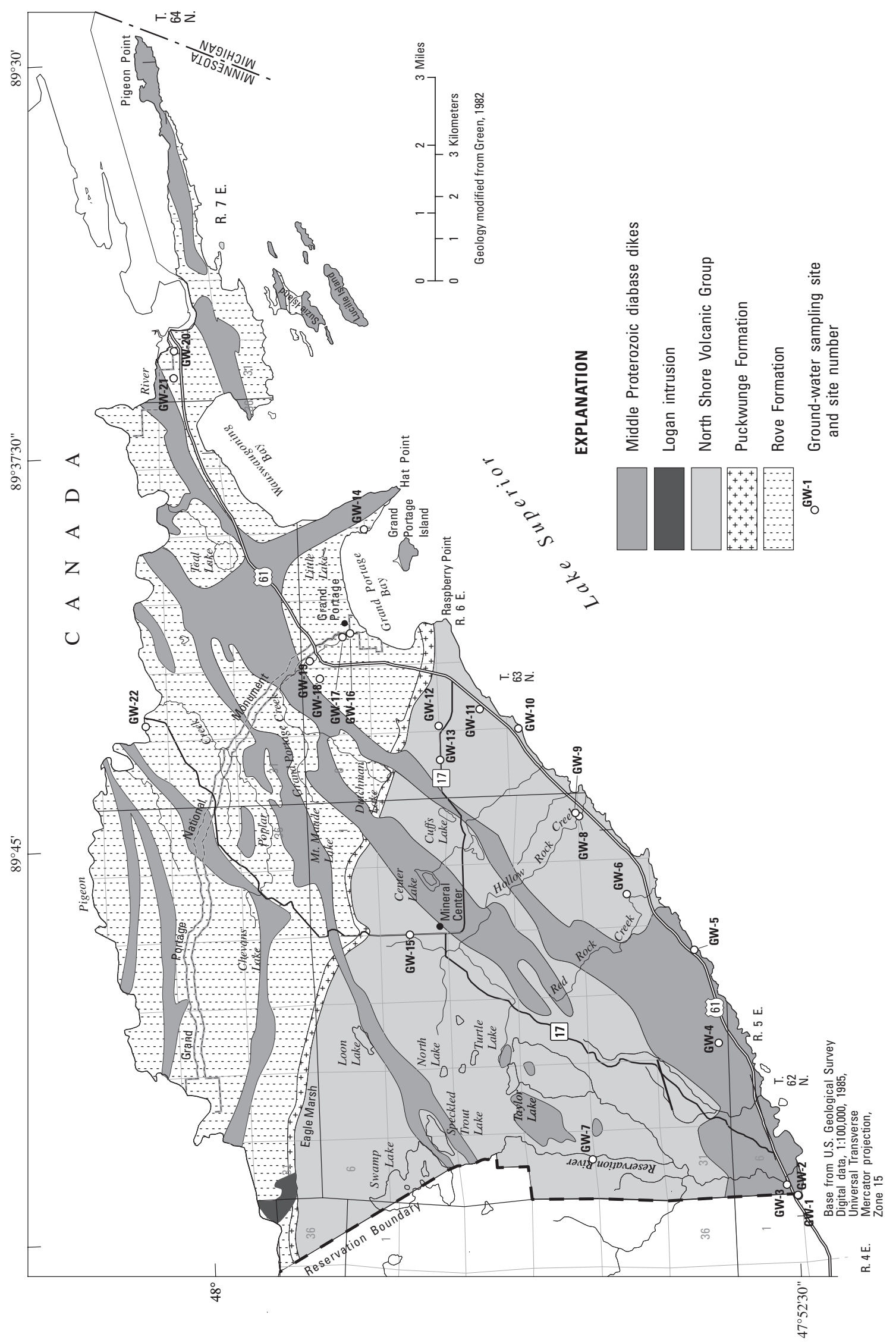

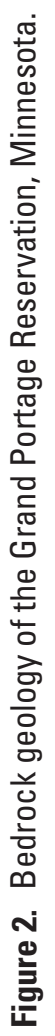


Swamp, Speckled Trout, and Loon Lakes (figs. 1 and 2).

Rivers and streams in the Grand Portage Reservation flow either to the Pigeon River or to Lake Superior (fig. $1)$. The courses of rivers and streams and the boundaries of their watersheds are influenced by the underlying bedrock geology of the Reservation. The diabase dikes form ridges in the Reservation. Several lakes lie between or alongside the following: Teal, Dutchman, Cuffs, Center, Speckled Trout, Swamp, and Loon Lakes. The ridges determine the course of several creeks-for example, the upstream portion of Grand Portage Creek flows parallel to the ridges. The contact between the North Shore Volcanic Group and the Puckwunge Formation is marked by a steep $200 \mathrm{ft}$ drop to Eagle Marsh Wetland north of Loon and Swamp Lakes. This contact also forms the southwestern boundary of the watersheds for Dutchman Lake and the headwaters of Grand Portage Creek.

\section{HYDROLOGY OF THE GRAND PORTAGE RESERVATION}

Ground water moves primarily through fractures in the bedrock beneath the Grand Portage Reservation because the glacial sediments that overlie the bedrock are thin, generally less than $50 \mathrm{ft}$ thick. Not much is known about the bedrock fractures under most of the Reservation. They have not been mapped because almost all the wells in the Reservation are located within 2 miles of Lake Superior. The fractures in two wells, RR and HRC in figure 1, were mapped by Paillet and Olson (1994) as part of a study on increasing well yield using hydrofracturing techniques.

The intersecting diabase dikes that cut all other bedrock units in the
Reservation may strongly influence fracture flow of water. The dikes are often crosscutting and may have deep vertical root zones that extend well below the surface, possibly creating barriers to shallow ground-water flow. The flat-lying Rove Formation is variably metamorphosed near dike margins and in some areas has been transformed into an impermeable hornfel rock. The dikes themselves may have intruded along large regional fractures and in turn may have created additional fractures during intrusion into other rock units.

Insight into the hydrogeology of the Grand Portage Reservation can be gained from a study of the former Finland Air Force Station, which is located about 75 miles southwest of the Reservation (U.S. Army Corps of Engineers, 1999) (fig. 1). The geology of the area surrounding the station is similar to the geology of the Reservation-thin unconsolidated material overlying the North Shore Volcanic Group intersected by diabase dikes (Green, 1982; U.S. Army corps of Engineers, 1999). A fracture analysis conducted for the former Finland Air Force Station study determined that greater than 50 percent of fractures in boreholes are typically encountered in the first $150 \mathrm{ft}$ of depth (Natural Resources Engineering Co., written commun., 2000). The station is underlain by two primary ground-water systems-a local system and a regional system. The local system is present primarily in the upper $100 \mathrm{ft}$ of bedrock, where fractures occur at a relative high density. This system receives recharge solely from infiltration of precipitation. Ground-water flow occurs within the fracture network and discharges to the surface at seeps, wetlands, and ponds (U.S. Army Corps of Engineers, 1999). The regional system is below the local system. Recharge to the regional sys- tem is from infiltration of precipitation, subsurface flow from upgradient lands, and leakage from the local system. Outside the immediate area of the station the regional system is shallow, at or near the land surface, and discharges to lowland lakes and rivers (U.S. Army Corps of Engineers, 1999). Fracture density in the regional system is controlled by geologic structures and is high near faults, dikes, and rock contacts.

Other studies have reported relatively well-connected, high-density fracture systems in the uppermost 100-200 ft of layered Paleozoic sedimentary bedrock including the Paleozoic bedrocks of southeastern Minnesota (A. Runkel, Minnesota Geological Survey, written commun., 2001). Wyrick and Borchers (1981) reported that in Appalachian valleys stress relief, the removal of compressional stress on underlying rocks by erosion of overlying rocks, results in predictable fracture patterns in valleys. The fractures are generally horizontal under valley floors and vertical along valley walls.

A local ground-water system may exist in the upper fracture zone of the bedrock beneath the Grand Portage Reservation if the hydrogeology is similar to that of the former Finland Air Force Station. This system would receive water from precipitation and discharge to seeps, springs, wetlands, ponds, and small creeks. Beneath this system would be a regional groundwater system that receives water that seeps from the local system. This system probably would discharge to Lake Superior, Pigeon River, and large rivers and creeks such as the Reservation River.

Regionally, the land surface descends from the interior of Minnesota and Canada to Lake Superior. As a result, water in the deepest ground- 
water system probably flows from the interior of Minnesota and Canada, and discharges to Lake Superior. Lake Superior may be the discharge area for brines in the deepest ground water (Shepard Miller, Inc., 1995, p. 5-8).

Ruhl (1995) estimated the storage coefficient (S) of the bedrock aquifers that discharge ground water to the Reservation River to be 1 x $10^{-4}$, which is typical of aquifers under confined conditions (Ruhl, 1995). The storage coefficient for these aquifers is small compared to the transmissivity (T). The hydraulic diffusivity (T/S) was estimated to be $9.0 \times 10^{5} \mathrm{ft}^{2} / \mathrm{d}$ (Ruhl, 1995). The high estimated hydraulic diffusivity indicates that effects from hydrologic stresses, such as ground-water withdrawals or recharge from rainstorms, are propagated rapidly in these aquifers (Ruhl, 1995).

The transmissivity of the bedrock aquifers around 17 wells completed in the aquifers ranged from 3 to $500 \mathrm{ft}^{2} / \mathrm{d}$ and had a median value of $20 \mathrm{ft}^{2} / \mathrm{d}$ (Ruhl, 1995). The transmissivities could not be predicted from the depth of bedrock penetration by wells. The reported well yield for 19 wells in Ruhl's study ranged from 1 to $100 \mathrm{gal} / \mathrm{min}$. The median well yield was $7 \mathrm{gal} / \mathrm{min}$. The well yield was greater in wells completed in the North Shore Volcanic Group than in wells completed in the diabase dikes and in the Rove Formation. The water level in 11 of 21 wells completed in the bedrock was above the top of the bedrock indicating that the aquifer was confined at these well locations (Ruhl, 1995).

Many of the springs in the Grand Portage Reservation go dry during summer. These springs probably are fed by discharge from the local system. However, several springs (SP-2,
3, and 6; fig. 1) flow year round and provide enough water to be used as a domestic water source. These springs likely are fed by the discharge from the regional system.

The watersheds of the streams in the Grand Portage Reservation are small (fig. 3) and stream slopes are steep. Ground-water quantities feeding the streams are not large because the unconsolidated material above the bedrock is thin. As a result, streams in the Reservation tend to be flashysharp rises during rainstorms and rapid declines afterwards. Stream discharges fall to zero or near-zero flow during periods of low rainfall. Generally, the greatest periods of runoff are in the spring, early summer, and fall because of spring snowmelt and rain, and early summer and fall rain. Streamflow decreases to base flow during the winter and during the summer when evapotranspiration exceeds rainfall. These patterns are illustrated by hydrographs for the Reservation River near Hovland, Minnesota, and Grand Portage Creek at Grand Portage, Minnesota (fig. 4).

The percent of precipitation at the Grand Portage Ranger Station that became runoff in the Grand Portage River and Reservation River watersheds from May 1991 through September 1992 was 40 and 45 percent, respectively. The percentage of precipitation at the Grand Marais weather station that became runoff in the Pigeon River from 1921-99 was 44 percent.

Lakes rise and fall with rainfall in the Grand Portage Reservation. This relation is illustrated by the lake stages of Loon and Cuffs Lakes (fig. $1)$, which were continuously measured during the ice free part of the year from June 1998 through November 2000. Lake levels in Loon and Cuffs Lakes decline when rainfall is below average and increase when rainfall is above average (fig. 5). The mean precipitation in figure 5 is the average of the daily precipitation from March 1, 1998, through December 31, 2000. The cumulative departure declines when precipitation is less than the mean for the period; it rises when the precipitation is greater than the mean and is level if the precipitation is equal to the mean.

\section{WATER QUALITY IN THE GRAND PORTAGE RESERVATION}

The data collected during 1991-98 and the methods used to collect the data are presented in Ruhl (1995 and 1997) and Winterstein (2000). The data collected during 1999-2000 and the methods used to collect the data are described in the Supplemental Information Section of this report. The sampling sites are shown in figure 1 and listed in table 1 .

The $\mathrm{pH}$ of water in the Reservation is generally alkaline ( $\mathrm{pH}$ greater than 7.0) (table 2). Only two wells (GW-15 and GW-22) had a $\mathrm{pH}$ of less than 7.0 (6.8). $\mathrm{pH}$ less than 7.0 was measured in two streams flowing from wetlands (sites SW-4 and SW-10) and in Center Lake and Cuffs Lake. The alkalinity, or acid neutralizing capability, of water in the Reservation is generally low, less than $100 \mathrm{mg} / \mathrm{L}$ as $\mathrm{CaCO}_{3}$ (table 2).

The concentrations of the major ions are much greater in ground water than in spring water and surface water in the Reservation. This difference is reflected in the measured specific conductance of the sampled wells, springs, and surface water (lakes and streams) (table 2). The concentrations of the major ions in the sampled water in $\mathrm{meq} / \mathrm{L}$ are shown in figures $6-8$. Some of the wells and surface-water sites 


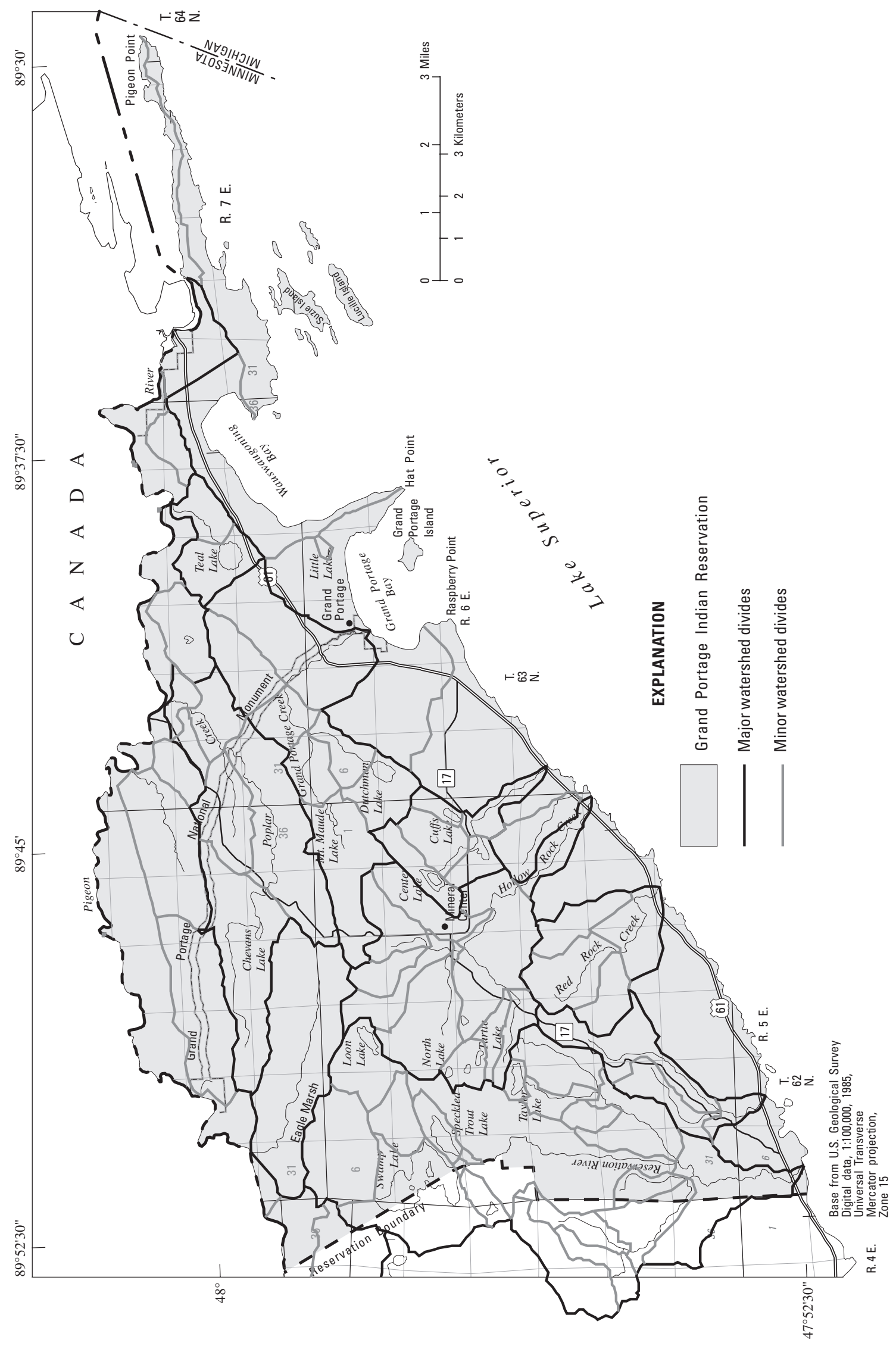

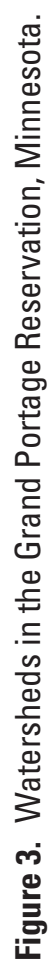



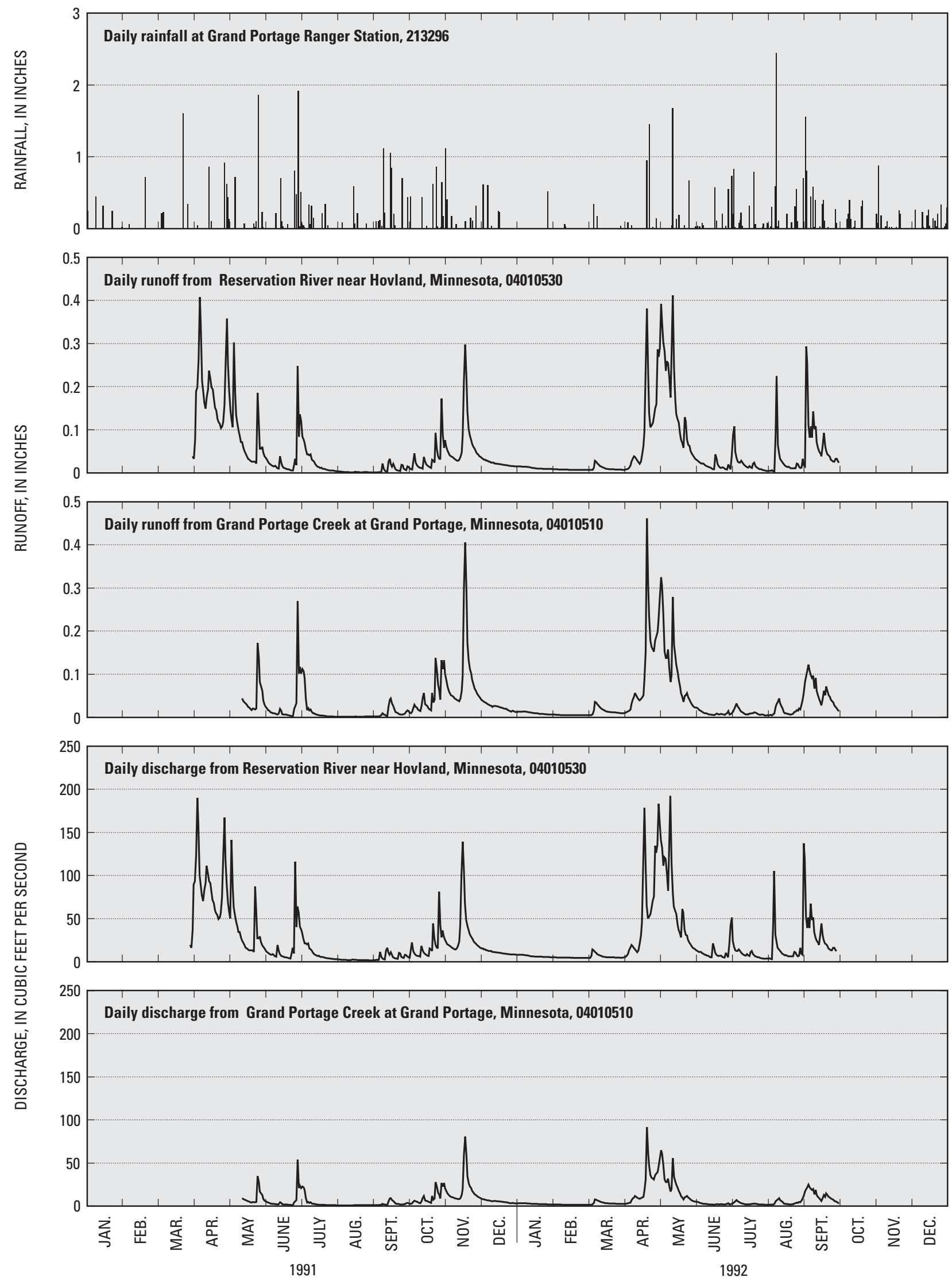

Figure 4. Discharge and runoff from Reservation River and Grand Portage Creek, Grand Portage Reservation, and rainfall at Grand Portage Ranger Station, Minnesota, 1991 and 1992. 

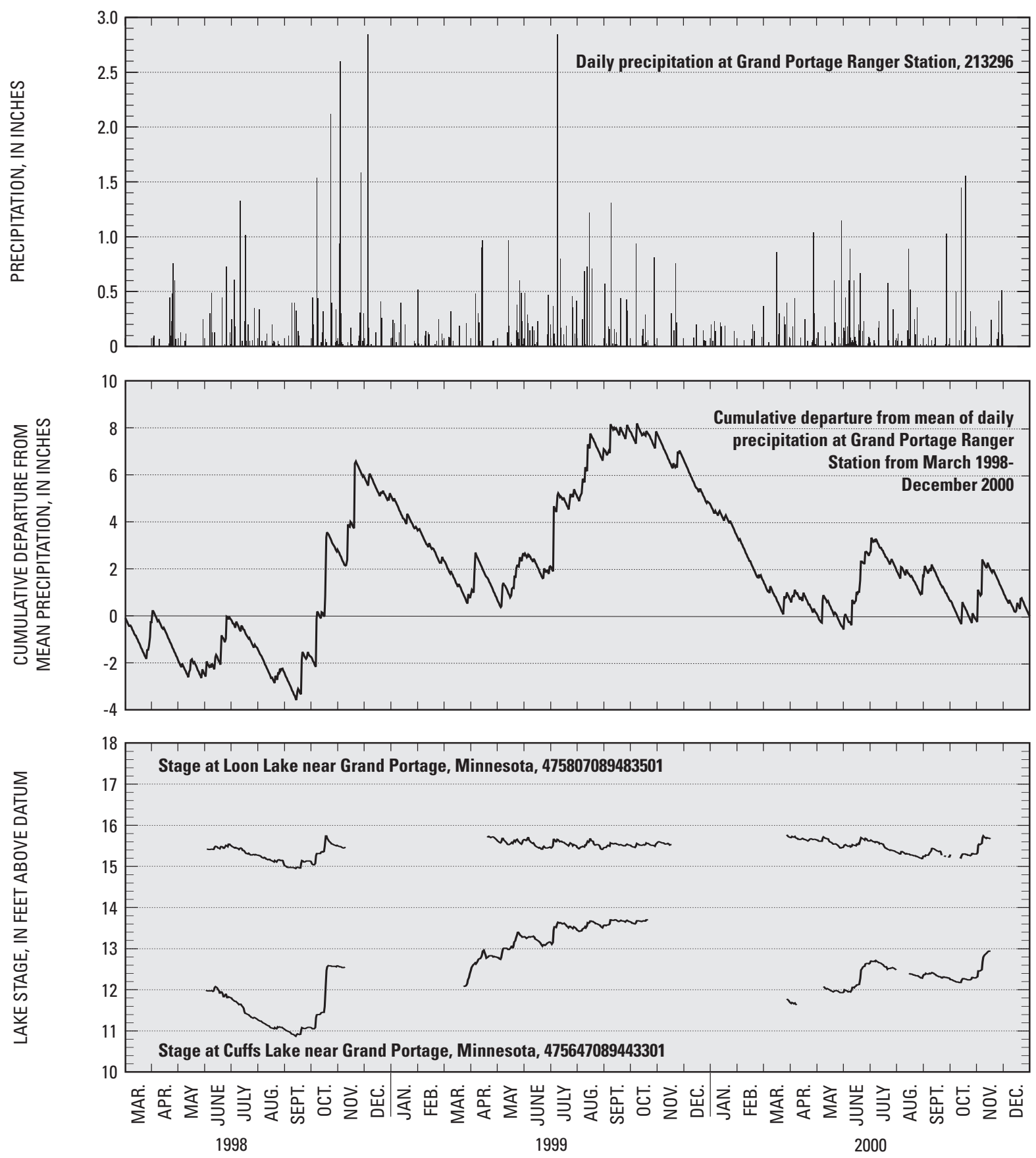

Figure 5. Daily precipitation at Grand Portage Ranger Station, cumulative departure from the mean of daily precipitation, and lake stages of Loon and Cuffs Lakes, Grand Portage Reservation, Minnesota, March 1998 through December 2000.

were sampled more than once. The ranges of the concentrations are shown in table 2 . The relative percentages of the major cations and anions in the samples are shown in figure 9.

Water from 11 of the 20 wells sampled is a calcium-sodium-chloride type (fig. 6). Water from GW-2, GW-
7, and GW-11 had much greater specific conductance concentrations of major ions compared to the other wells (fig. 6). The greater concentrations of calcium, sodium, and chloride in these wells may be from the dissolution of the rock matrix (Shepard Miller, Inc., 1995, p. 5-9), or the upward discharge of brines from the underlying Precambrian rocks (Kelly and others, 1986, Shepard Miller, Inc., 1995, p. 5-8, F. Paillet, U.S. Geological Survey, written comm., January 5, 1998). Water that is compositionally similar to the water in these wells has been found in the Canadian Shield and in the upper peninsula of Michigan (Kelly and others, 


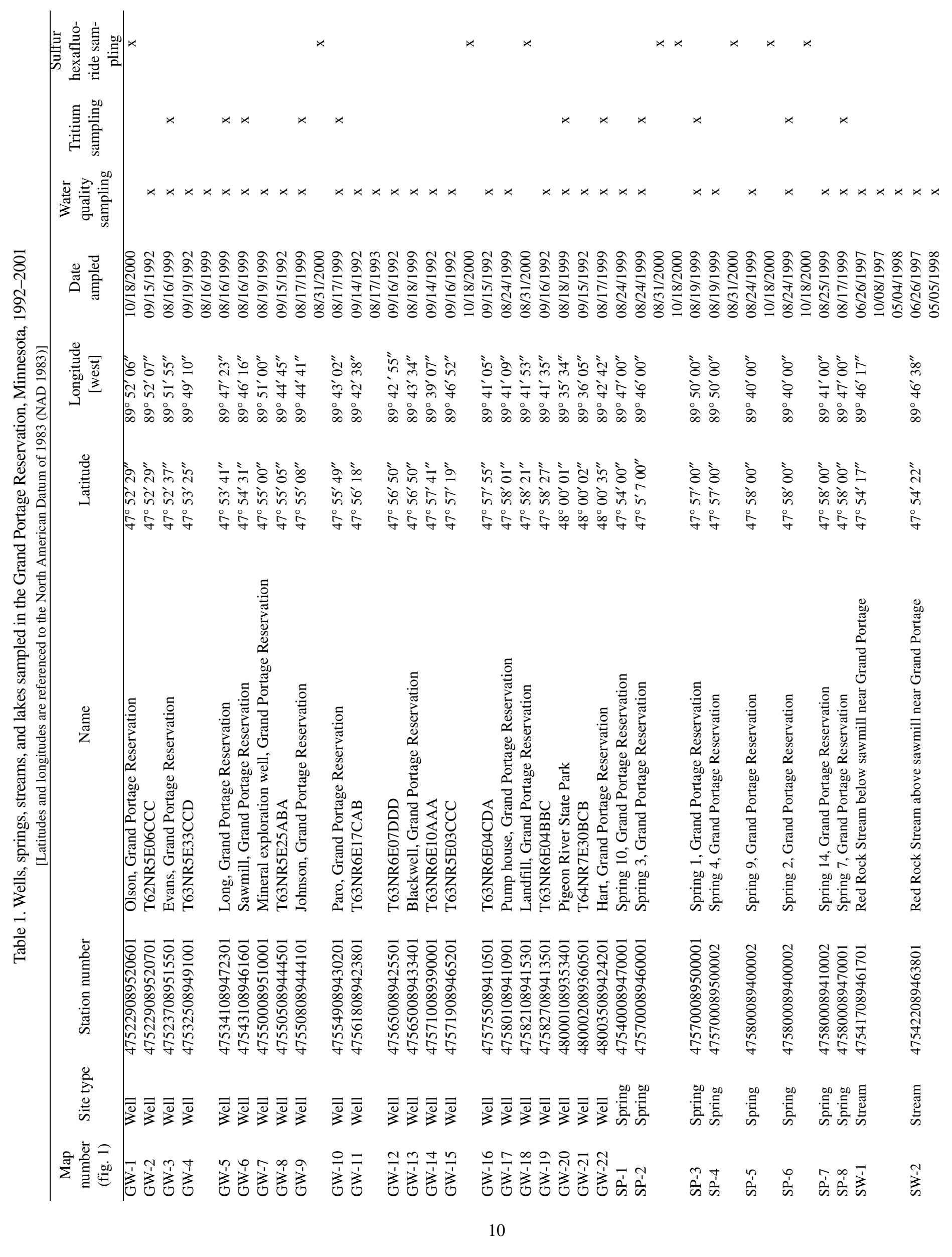




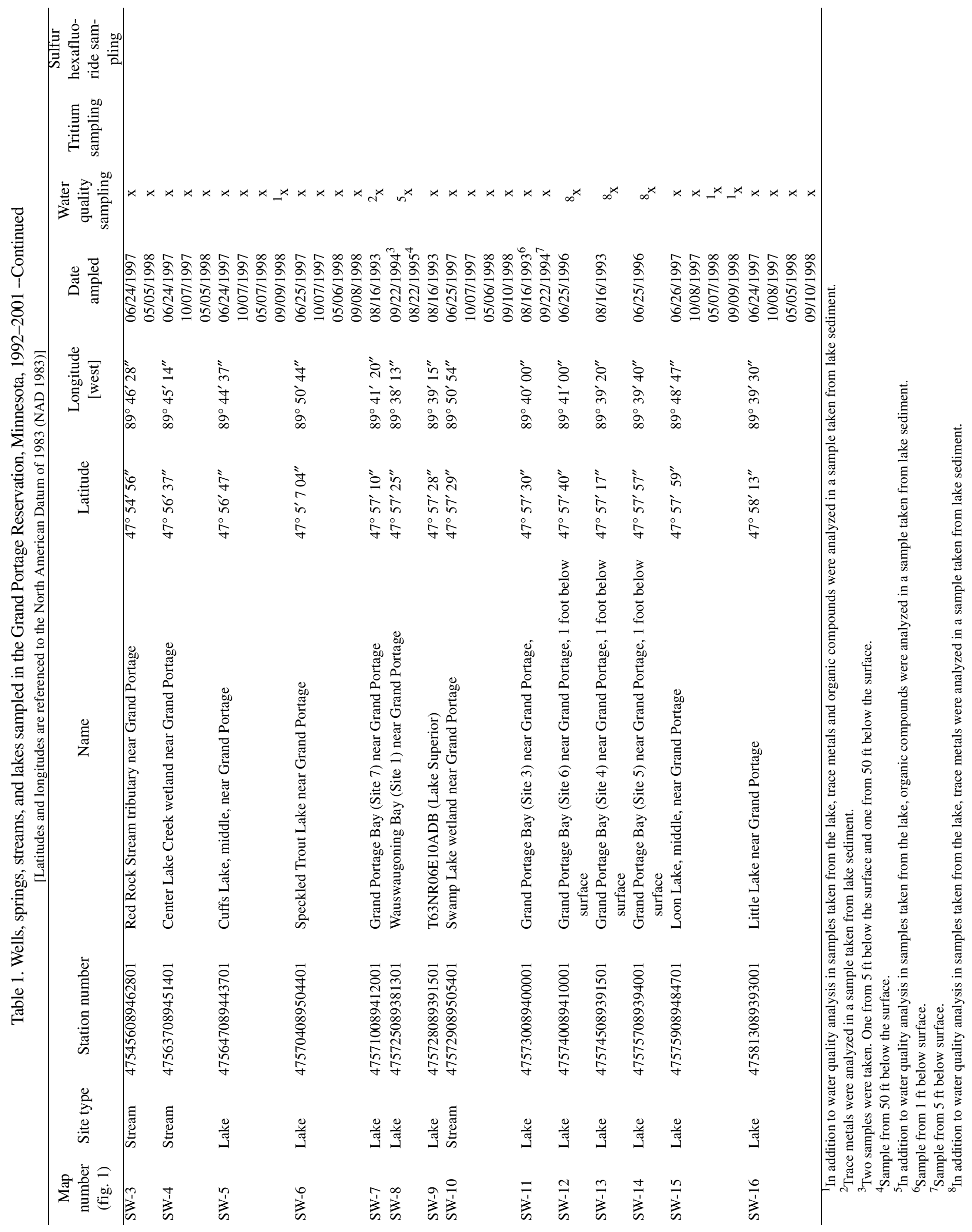


Table 2. Ranges of $\mathrm{pH}$, alkalinity, specific conductance, and ionic concentrations of water sampled in the Grand Portage Reservation, Minnesota, 1992-99

[Data from Ruhl, 1995, 1997; Winterstein, 2000; data collected 1999-2000 by the U.S. Geological Survey; additional specific conductance and pH data from Margaret Watkins, Grand Portage Reservation, written comm., 2000]

\begin{tabular}{|c|c|c|c|c|}
\hline Property & Values & $\begin{array}{c}\text { Ground water } \\
\text { sampled between } \\
1992-99\end{array}$ & $\begin{array}{c}\text { Spring water } \\
\text { sampled in } 1999\end{array}$ & $\begin{array}{c}\text { Surface water } \\
\text { sampled between } \\
\text { 1993-98 }\end{array}$ \\
\hline \multirow[t]{4}{*}{ Specific conductance, $\mu \mathrm{S} / \mathrm{cm}$} & Minimum & 94 & 50 & 17 \\
\hline & Maximum & 5,250 & 252 & 164 \\
\hline & Average & 1,332 & 132 & 60 \\
\hline & Number of values & 22 & 8 & 76 \\
\hline \multirow[t]{4}{*}{$\mathrm{pH}$, standard units } & Minimum & 6.81 & 5.7 & 5.6 \\
\hline & Maximum & 10.2 & 8.6 & 9 \\
\hline & Average & 8.3 & 6.8 & 7.4 \\
\hline & Number of values & 22 & 8 & 75 \\
\hline \multirow[t]{4}{*}{ Alkalinity, $\mathrm{mg} / \mathrm{L}$ as $\mathrm{CaCO}_{3}$} & Minimum & 17 & 17 & 6 \\
\hline & Maximum & 205 & 61 & 78 \\
\hline & Average & 73 & 46 & 29 \\
\hline & Number of values & 22 & 8 & 35 \\
\hline \multirow{4}{*}{$\begin{array}{l}\text { Total concentration of ions in a sample, } \\
\mathrm{meq} / \mathrm{L}\end{array}$} & Minimum & 2.0 & 1.0 & 0.4 \\
\hline & Maximum & 80.4 & 4.7 & 3.6 \\
\hline & Average & 22.1 & 2.7 & 1.4 \\
\hline & Number of values & 19 & 8 & 35 \\
\hline
\end{tabular}

1986; Shepard Miller, Inc., 1995, F. Paillet, U.S. Geological Survey, written comm., January 5, 1998). Lake Superior has been interpreted as a regional discharge area for deep brines (Shepard Miller, 1995, p. 5-8). Paillet and Olson (1994) reported that saline water (fluid conductivity of about 2 ohm-meters at $8{ }^{\circ} \mathrm{C}$, corresponding to a total dissolved solids of about 4,000 $\mathrm{mg} / \mathrm{L}$ ) in a borehole drilled near Hollow Rock Creek (HRC) (fig. 1) came from depths greater than $200 \mathrm{ft}$. The salty water in GW-2, GW-7, and GW-11 could be the result of mixing of fresh rain water with the deeper brine (Shepard Miller, 1995, p. 5-8; F. Paillet, U.S. Geological Survey, written comm., January 5, 1998). Two of the wells are domestic supply wells, GW-2 and GW-11. The third well, GW-7, is believed to be a mineral exploration well (M. Watkins, Grand Portage Reservation, oral comm., 2000).

Although wells GW-2 and GW-3 are close to each other (about $1,100 \mathrm{ft}$ apart), are completed the same type of bedrock, and the elevations of the bottom of the wells are about the same (table 1), the ionic composition of samples from these wells are very different (fig. 6). Water in well GW-2 is a calcium-sodium-chloride type, whereas water in well GW-3 is a sodium-bicarbonate type. The total ionic concentration in well GW-2 is $91.06 \mathrm{meq} / \mathrm{L}$; the total ionic concentration in well GW-3 is $6.56 \mathrm{meq} / \mathrm{L}$. Two reasons could explain these differences in water quality. First, well GW-2 is about $100 \mathrm{ft}$ from Lake Superior and well GW-3 is about $1,000 \mathrm{ft}$ from the lake. It is likely that the source of water to well GW-2 is from a regional and deeper groundwater system that intersects some of the brine that discharges to Lake Superior. Well GW-3 is farther from the lake and may not intersect the flow of the brine. Second, well GW-3 is about $300 \mathrm{ft}$ from Reservation River and may intersect fractures that receive discharge that flows down- ward from the Reservation River to the ground water.

The ionic composition of the water sampled from well GW-11 during September 1992 is very different than that of the water sampled from the well during August 1993 (fig. 6). The sampled water may come from two different sources. Water in a well completed in fractured rock may be a mixture of shallow and deep ground water. This mixture may change seasonally or following rain storms. The water sampled in 1992 probably came from deep ground water considering that its ionic composition is similar to water from wells GW-2 and GW-7, which are also deep wells (table 1, fig. 6). The water sampled in 1993 probably came from shallow ground water considering that its ionic concentrations are similar to water from springs (figs. 6 and 7).

The ionic composition of water from wells GW-15 and GW-22 is similar to the ionic composition of surface waters (fig. 9). The concentra- 
Calcium

Magnesium

Sodium and

Potassium

Calcium

Magnesium

Sodium and

Potassium

Calcium

Magnesium

Sodium and

Potassium

Calcium

Magnesium

Sodium and

Potassium

Calcium

Magnesium

Sodium and

Potassium

Calcium

Magnesium

Sodium and

Potassium

Calcium

Magnesium

Sodium and

Potassium

Calcium

Magnesium

Sodium and

Potassium

Calcium

Magnesium

Sodium and

Potassium

Calcium

Magnesium

Sodium and

Potassium

Calcium

Magnesium Sodium and Potassium

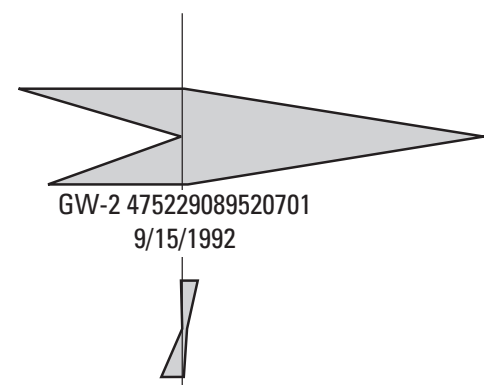

GW-3 475237089515501 $8 / 16 / 1998$

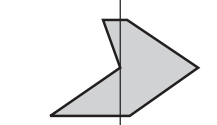

GW-4 475325089491001 9/19/1992

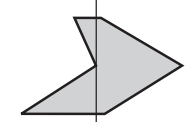

GW-4 475325089491001 $8 / 19 / 1999$

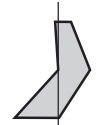

GW-5 475341089472301 8/16/1999

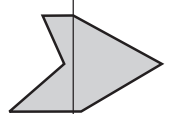

GW- 6475431089461601 8/16/1999

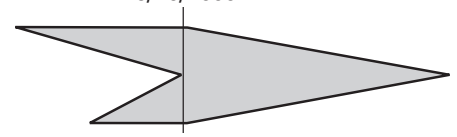

GW-7 475500089510001 $8 / 19 / 1999$

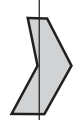

GW-8 475505089444501 9/15/1992

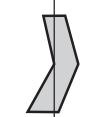

GW-9 475508089444101
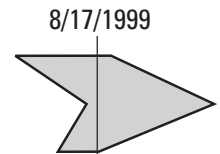

GW-10 475549089430201

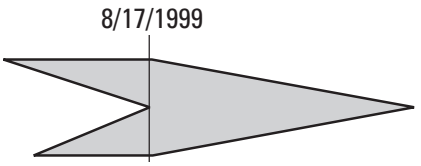

GW-11 475618089423801 9/14/1992
GW-11 475618089423801 $8 / 17 / 1993$

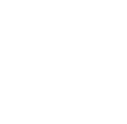

GW-12 475650089425501 9/16/1992

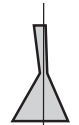

GW-13 475650089433401 8/18/1999<smiles>C=C</smiles>

GW-14 475710089390001 9/14/1992

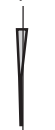

GW-15 475719089465201 9/16/1992

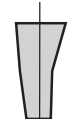

GW-16 475755089410501 9/15/1992

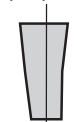

GW -17 475801089410901 8/24/1999

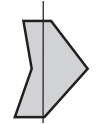

GW-19 475827089413501 9/16/1992

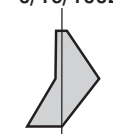

GW-20 480001089353401 8/18/1999

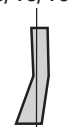

GW-21 480002089360501 9/15/1992

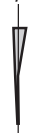

GW-22 480035089424201

$8 / 17 / 1999$
Carbonate and Bicarbonate

Chloride and Fluoride Sulfate

Carbonate and Bicarbonate

Chloride and Fluoride Sulfate

Carbonate and Bicarbonate

Chloride and Fluoride Sulfate

Carbonate and Bicarbonate

Chloride and Fluoride Sulfate

Carbonate and Bicarbonate

Chloride and Fluoride Sulfate

Carbonate and Bicarbonate

Chloride and Fluoride Sulfate

Carbonate and Bicarbonate

Chloride and Fluoride Sulfate

Carbonate and Bicarbonate

Chloride and Fluoride Sulfate

Carbonate and Bicarbonate

Chloride and Fluoride Sulfate

Carbonate and Bicarbonate

Chloride and Fluoride Sulfate

Carbonate and Bicarbonate

Chloride and Fluoride Sulfate

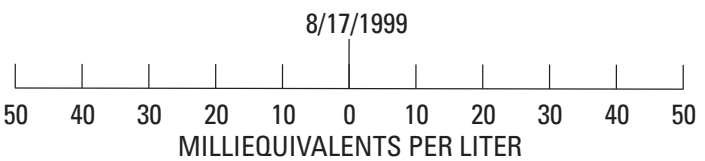

Figure 6. Concentrations of cations and anions in water sampled from wells in the Grand Portage Reservation, Minnesota, 1992-99. 


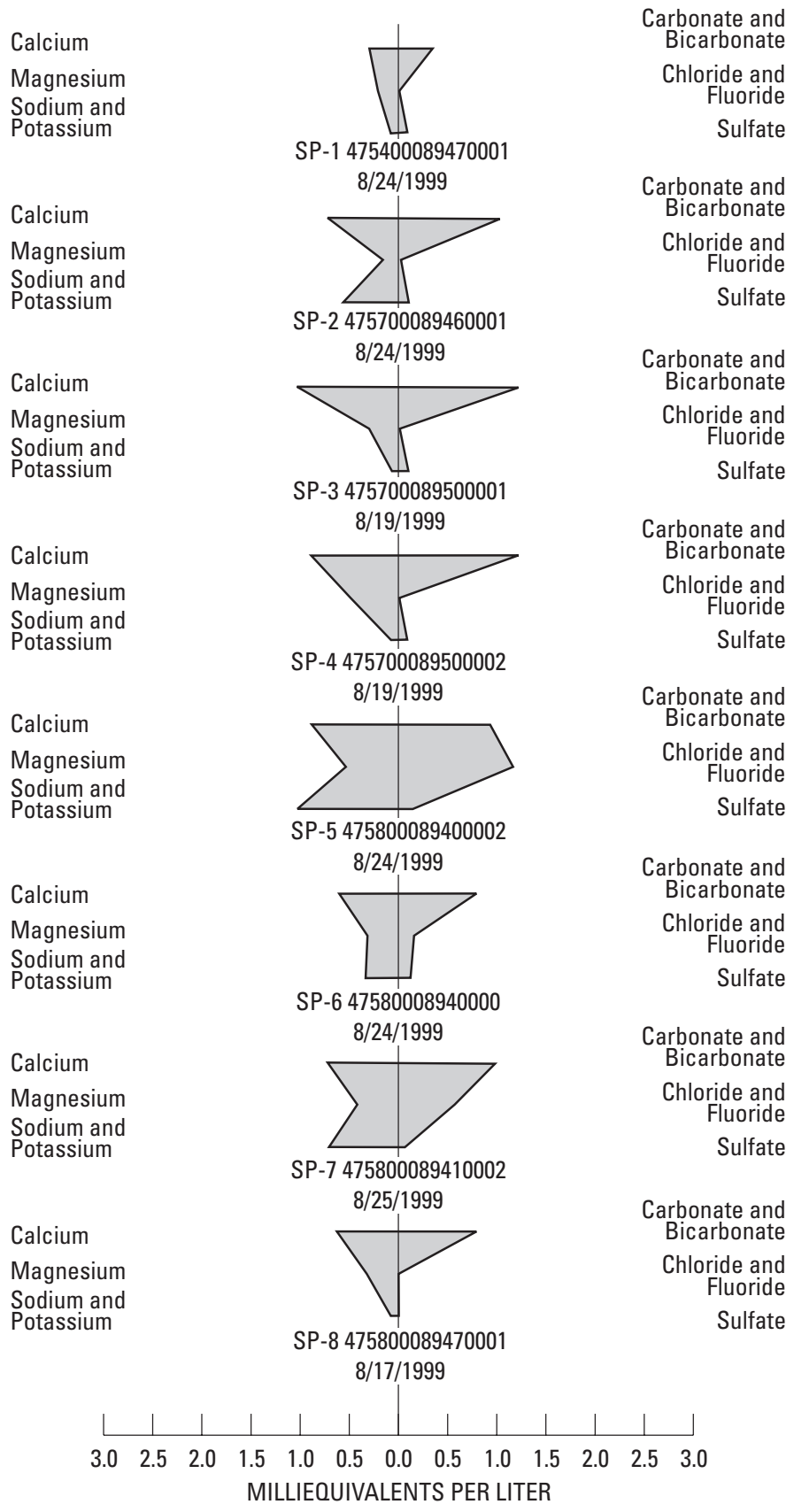

Figure 7. Concentrations of cations and anions in water sampled from springs in the Grand Portage Reservation, Minnesota, 1992-99.

tions of ions in the water from these wells are less than $3 \mathrm{meq} / \mathrm{L}$ (fig. 6), the same as spring and surface waters (figs. 7 and 8). Well GW-15 is $275 \mathrm{ft}$ deep and well GW-22 is $47 \mathrm{ft}$ deep. The recharge age of the water in well GW-15 is about 1.5 years based upon recharge-age dating by sulfur hexafluoride methods. It is likely that the water in the well GW-15 is from bedrock fractures that contain recently recharged ground water.

Percentages of major ion concentrations in ground water, springs, lakes, and streams in the Reservation are shown in figure 9. Spring water generally plots between surface waters and ground waters indicating that spring water is a mixture of surface and ground waters (fig. 9). This mixing can also be seen in figure 7 . Some spring water (SP-1, SP-3, SP-4, SP-6, and SP-8) is calcium-bicarbonate type water like surface water, while other spring water (SP-5 and SP-7) is similar to the calcium-sodium-chloride type water in samples from about onehalf of the wells.

The major chemical constituents in surface water are bicarbonate, calcium, and magnesium. The ionic concentrations for the three sampling sites in Lake Superior, SW-8, SW-9, and SW-11, are almost identical (fig. 8). Water samples from lakes show almost no seasonal variation in ionic concentrations, whereas water samples from streams show seasonal variation (SW1 and SW-10; fig. 8). The concentrations of the calcium cation and bicarbonate and carbonate anions increase in streams during periods of low flow (samples taken in September and October, sites SW-1 and SW-10; fig. 8). The water in the streams during periods of low flow is composed primarily of shallow ground water. The diagrams in figure 8 during low flow are very similar to the diagrams for springs SP3, SP-4, and SP-8 (fig. 7). Stream sites SW-2 and SW-3 were not sampled during fall 1997 because both were dry. Stream sites SW-1, SW-2, and SW-3 were dry during fall 1998.

The concentrations of ions in Loon Lake (SW-15) (fig. 8) are substantially less than in Cuffs Lake (SW-5), Speckled Trout Lake (SW-6), and Little Lake (SW-16). Loon Lake is located in the highest area of the Grand Portage Reservation, and the low ionic concentrations may occur because little ground water flows into the lake. The concentrations of ions in Little Lake are substantially greater than in the other lakes. Little Lake is spring fed (Margaret Watkins, Grand Portage Reservation, oral comm., 2001), and 
the ionic concentrations are similar to those for springs (fig. 7 and 8).

Physical data collected from seven lakes within the Grand Portage Reservation are listed in table 4 . The data were collected during 1997-2000 by the USGS and the Grand Portage Reservation Environmental Department (Margaret Watkins, Grand Portage Reservation, written comm., 2000). The USGS collected data from four lakes and the Grand Portage Reservation collected data from five lakes (table 4). Physical and chemical parameters that were measured include specific conductance, $\mathrm{pH}$, oxygen reduction potential, temperature, turbidity, and dissolved oxygen. The parameters were measured with a portable, multiparameter meter. The measurements listed in table 4 were made in the center of each lake about $1 \mathrm{ft}$ below the surface.

Temperature and dissolved oxygen measurements in Center Lake indicate that the lake is fed by ground water. Center Lake is in a valley on top of a dike (fig. 2). Although, Center Lake is a very shallow lake, about $12 \mathrm{ft}$ deep, temperature and dissolved oxygen measurements show that the lake stratifies during the summer (fig. 10). The temperature in the hypolimnion remains constant at about $7^{\circ} \mathrm{C}$ all summer. Typically, the hypolimnion warms during the summer, as it does for Taylor Lake (fig. 10). In addition, the dissolved oxygen near the bottom of Center Lake remains less than 1 $\mathrm{mg} / \mathrm{L}$ all summer.

Quality requirements for drinking water are the most stringent of water-quality standards, and thus are conservative standards against which to evaluate water-quality data. The U.S. Environmental Protection Agency (USEPA) has established drinking-water standards and health advisories for some of the constituents in the water in the Reservation (U.S. Environmental Protection Agency, 2000). USEPA promulgates two levels of drinking-water standards. Maximum contaminant levels (MCLs) are the highest level of a contaminant that is allowed in drinking water. MCLs are enforceable standards. Secondary drinking-water regulations (SDWRs) are non-enforceable Federal guidelines regarding cosmetic effects (such as tooth or skin discoloration) or aesthetic effects (such as taste, odor, or color) of drinking water. Several categories of non-enforceable health advisories (HAs) also exist. The most stringent of the HAs is the lifetime HA, which is defined by the USEPA as "the concentration of a chemical in drinking water that is not expected to cause any adverse noncarcinogenic effects for a lifetime of exposure." Table 5 lists the sampled constituents for which standards and advisories exist.

\section{DETERMINING THE RECHARGE AGE OF WATER FROM THE GRAND PORTAGE RESERVATION}

Water from selected wells and springs was analyzed for recharge-age dates to determine when the water fell as precipitation. Two environmental tracers were used to date the watertritium and sulfur hexafluoride $\left(\mathrm{SF}_{6}\right)$.

\section{TRITIUM CONCENTRATIONS AND SOURCES}

Tritium, a radioactive isotope of hydrogen, has two possible sources in water in the study area. First, it is naturally and continually produced in the upper atmosphere by cosmic ray bombardment. Tritium concentrations measured in precipitation near
Ottawa, Canada, before nuclear device testing were about $48 \mathrm{pCi} / \mathrm{L}$ (picocuries per liter). Second, tritium was produced by atmospheric nuclear-device testing from the early 1950's through the mid 1960's. This testing greatly increased tritium concentrations in the atmosphere and in precipitation from 1953 through the mid 1980's. Tritium concentrations in precipitation from nuclear-device testing peaked in 1963 (Clark and Fritz, 1997). Maximum tritium concentrations measured in precipitation at Ottawa, Canada, were 18,612 pCi/L in June 1963 (International Atomic Energy Agency/World Meteorological Organization, 1998).

Tritium concentrations in precipitation vary throughout the year. The greatest transfer of tritium from the stratosphere to the troposphere occurs during the spring in mid-latitude zones (Clark and Fritz, 1997). This is due to seasonal disturbances in this boundary by displacement of the jet stream as upper level air circulation reorganizes in the spring. This "spring leak" annually recharges the hydrosphere with tritium. Tritium concentrations have been declining in precipitation since the peak in 1963 . The decline of tritium in precipitation is due not only to radioactive decay, which decreases tritium levels by 5.5 percent per year, but also because tritium is being stored in ground water and oceans and is not being returned to the atmosphere (Clark and Fritz, 1997).

Two sources of tritium concentrations in precipitation were used in the analysis. Tritium concentrations in precipitation from 1953-86 are from the computer program DEP.BAS (Brian Cross, U.S. Geological Survey, written commun., 2001). These concentrations are estimates of the concentration in precipitation near the Grand Portage Reservation at the 


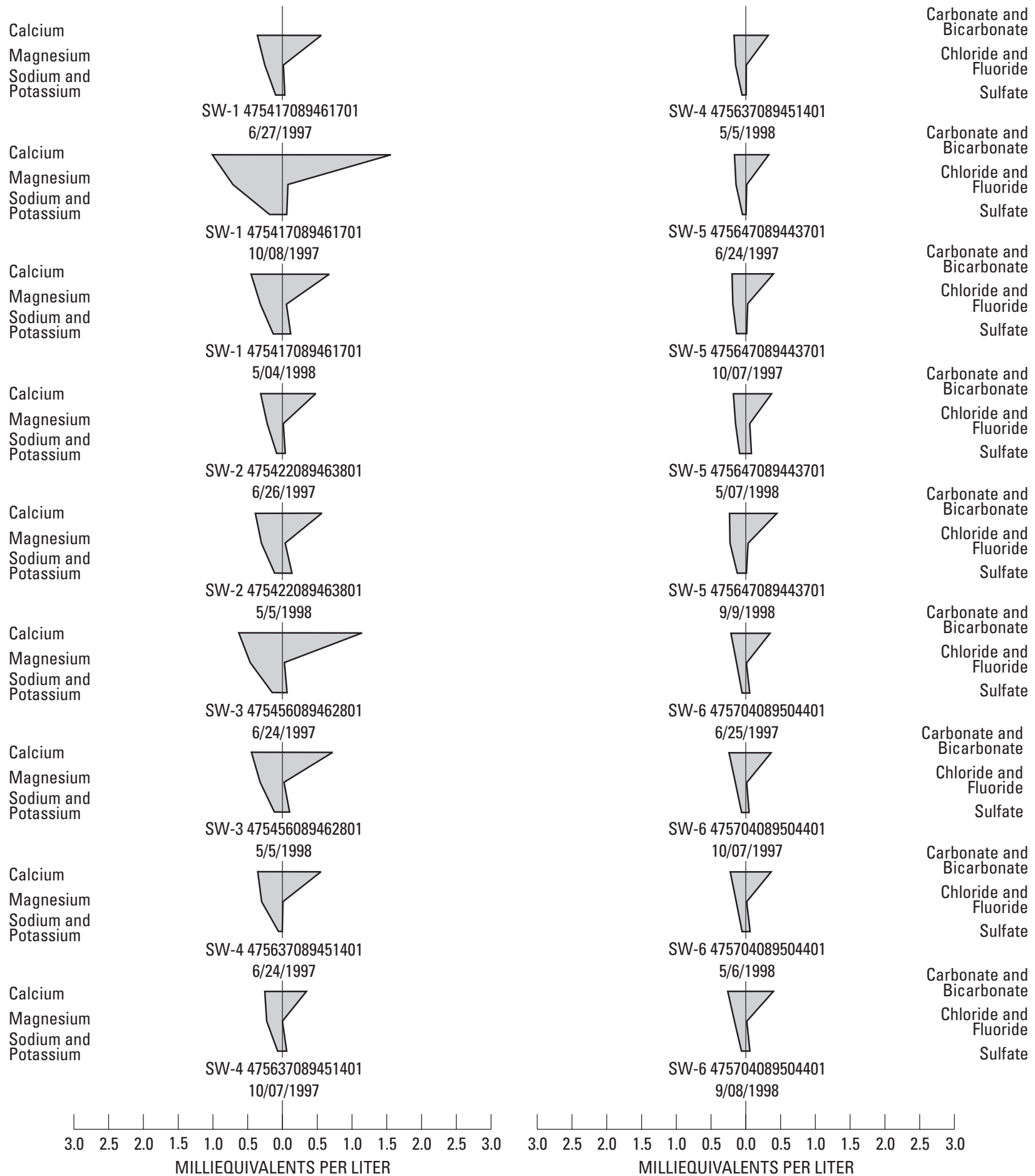

Figure 8. Concentrations of cations and anions in water sampled from

beginning of each month. The estimates were developed using procedures described in Michel (1989a and 1989b). The Minnesota Department of Health measured the tritium in precipitation at the beginning of each month from April 1996 through June
1999 at Ely, Minnesota, 62 miles west of the Grand Portage Reservation (fig. 1) (James F. Walsh, Minnesota Department of Health, written commun., 2001).

Tritium decays with a half-life of 12.43 years. For the purposes of com- parison in this report, all tritium concentrations measured in precipitation have been adjusted for radioactive decay to August 15, 1999. Ground water that was precipitation before atmospheric nuclear-device testing began now has a tritium concentration 
Calcium

Magnesium

Sodium and

Potassium

Calcium

Magnesium

Sodium and

Potassium

Calcium

Magnesium

Sodium and

Potassium

Calcium

Magnesium

Sodium and

Potassium

Calcium

Magnesium

Sodium and

Potassium

Calcium

Magnesium

Sodium and

Potassium

Calcium

Magnesium

Sodium and

Potassium

Calcium

Magnesium

Sodium and

Potassium

Magnesium

Sodium and

Potassium

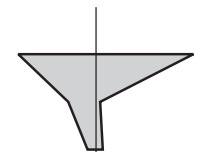

SW-8 475725089381301

9/22/1994 (5 feet below surface)

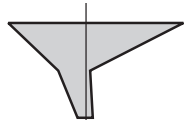

SW-8 475725089381301

9/22/1994 (50 feet below surface

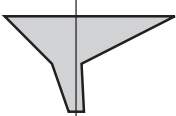

SW-8 475725089381301

$$
8 / 22 / 1995
$$

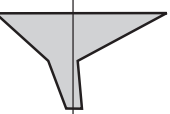

SW-9 475728089391501

$8 / 16 / 1993$

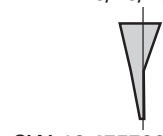

SW-10 475729089505401
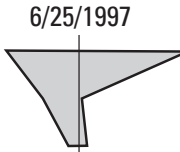

SW-10 475729089505401

10/07/1997

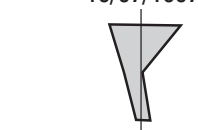

SW-10 475729089505401
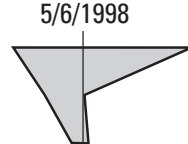

SW-10 475729089505401

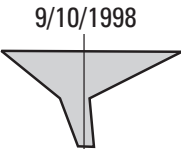

SW-11 475730089400001 8/16/1993

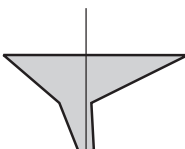

SW-11 475730089400001

9/22/1994

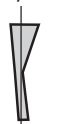

SW-15 475759089484701

6/26/1997

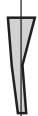

SW-15 475759089484701 10/8/1997

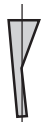

SW-15 475759089484701 $5 / 07 / 1998$

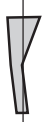

SW-15 475759089484701

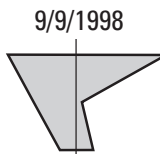

SW-16 475813089393001
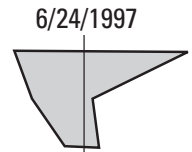

SW-16 475813089393001

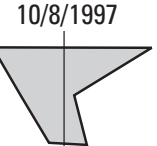

SW-16 475813089393001

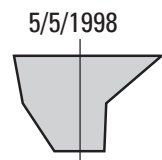

SW-16 475813089393001 9/10/1998
Carbonate and Bicarbonate

Chloride and Fluoride

Sulfate

Carbonate and Bicarbonate

Chloride and Fluoride

Sulfate

Carbonate and Bicarbonate

Chloride and Fluoride Sulfate

Carbonate and Bicarbonate

Chloride and Fluoride Sulfate

Carbonate and Bicarbonate

Chloride and Fluoride Sulfate

Carbonate and Bicarbonate

Chloride and Fluoride

Sulfate

Carbonate and Bicarbonate

Chloride and Fluoride

Sulfate

Carbonate and Bicarbonate

Chloride and Fluoride

Sulfate

Carbonate and Bicarbonate

Chloride and Fluoride Sulfate
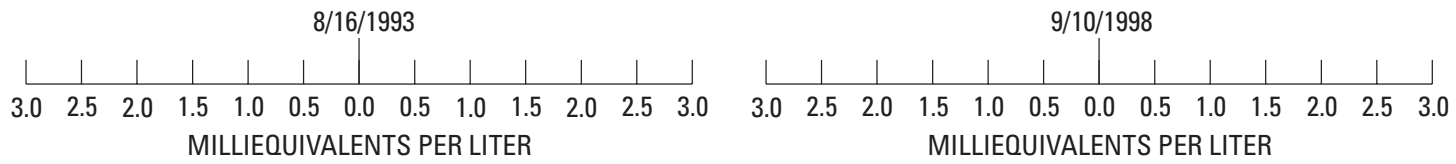

lakes and streams in the Grand Portage Reservation, Minnesota, 1992-99.

of $<3 \mathrm{pCi} / \mathrm{L}$. The maximum estimated concentration of tritium in precipitation near the Grand Portage Reservation was about $17,500 \mathrm{pCi} / \mathrm{L}$ in June 1963. Adjusted for decay to August 15,1999 , the tritium in ground water recharged by this precipitation would be about 2,500 $\mathrm{pCi} / \mathrm{L}$. The adjusted tritium curve is shown in figure 11 . The tritium concentrations measured in water from eight wells and four springs of the Grand Portage Reservation during August 1999 are shown in table 6 and figure 11 .

\section{SULFUR HEXAFLUORIDE SOURCES AND CONCENTRATIONS}

Sulfur hexafluoride $\left(\mathrm{SF}_{6}\right)$ concentrations were determined in water 


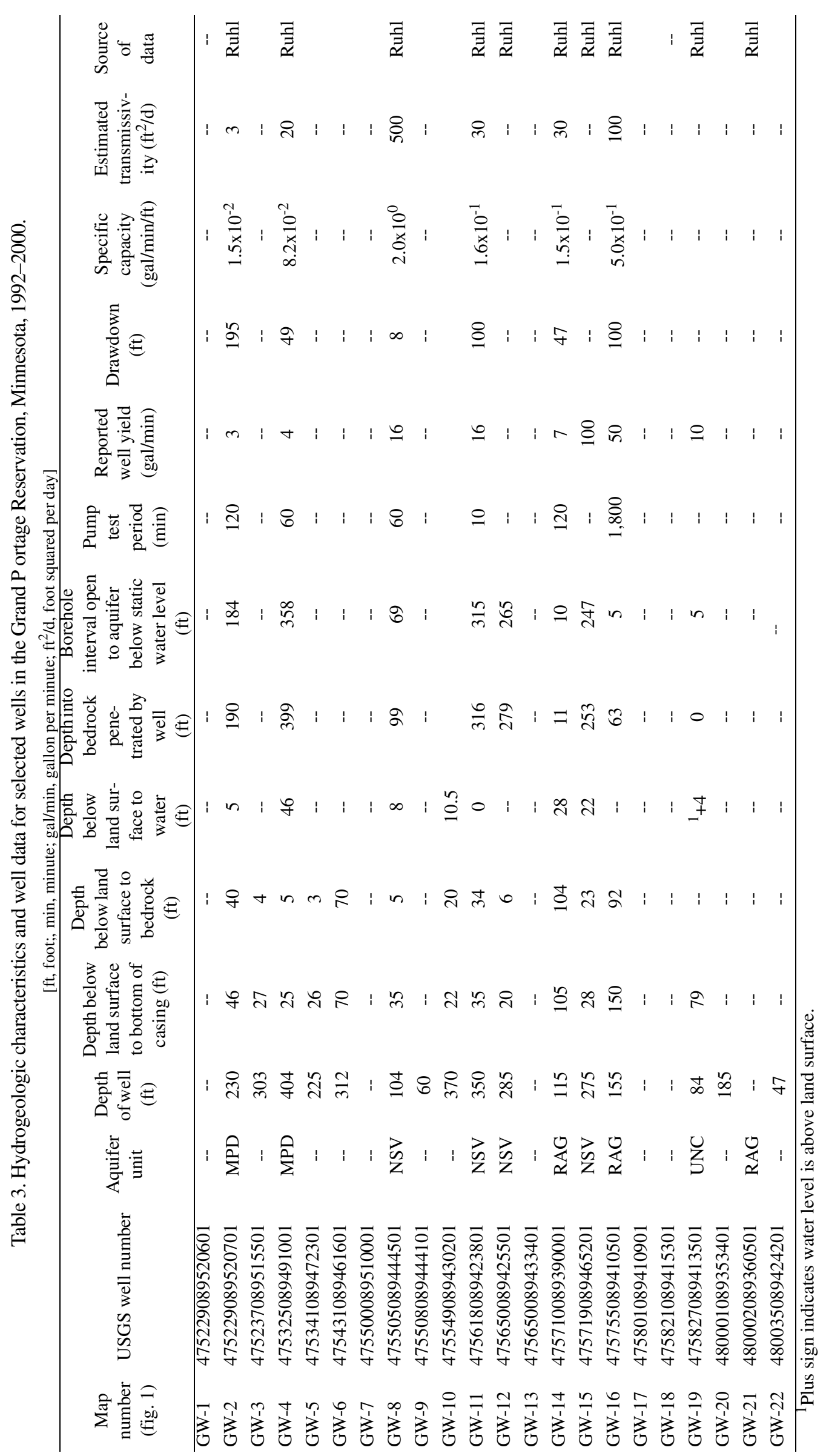




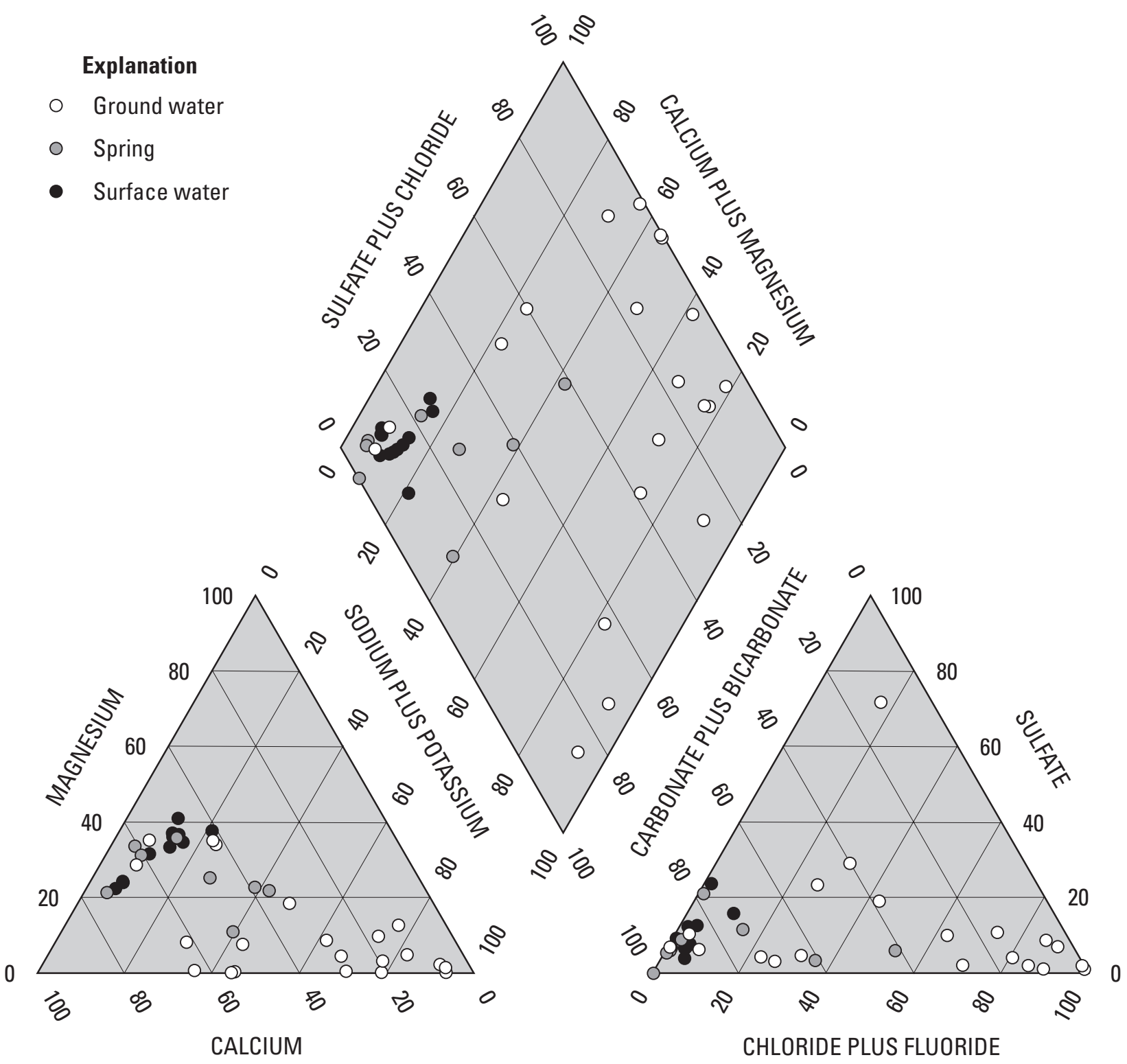

PERCENT OF TOTAL MILLIEQUIVALENTS PER LITER

Figure 9. Percentage distribution of major ion concentrations in water samples from ground water, springs, lakes, and streams in the Grand Portage Reservation, Minnesota, 1992-99.

sampled from four wells and four springs during August and October 2000 (tables 1 and 7). Sulfur hexafluoride is a trace atmospheric gas that is primarily of anthropogenic origin but also occurs naturally in fluid inclusions in some minerals and igneous rocks, and in some volcanic and igneous fluids (Busenberg and Plummer, 1997; 2000). Atmospheric concentrations of $\mathrm{SF}_{6}$ are expected to continue increasing. $\mathrm{SF}_{6}$ is also apparently stable in reducing ground-water environments, and because there are relatively few uses of the compound, few environments are contaminated by anthropogenic sources. Ground water can be dated with $\mathrm{SF}_{6}$ if it is in equilibrium with atmospheric $\mathrm{SF}_{6}$ at the time of recharge, and does not contain significant $\mathrm{SF}_{6}$ from other sources.
The dating range of $\mathrm{SF}_{6}$ is after 1970 (Busenberg and Plummer, 2000).

The estimated recharge ages of the samples from four wells and four springs are in table 7 . The remarks code of four of the samples indicated that there was about a 1-mL air space beneath the caps of the sampling bottle. This can contaminate the samples with $\mathrm{SF}_{6}$ that was in the air at the time 


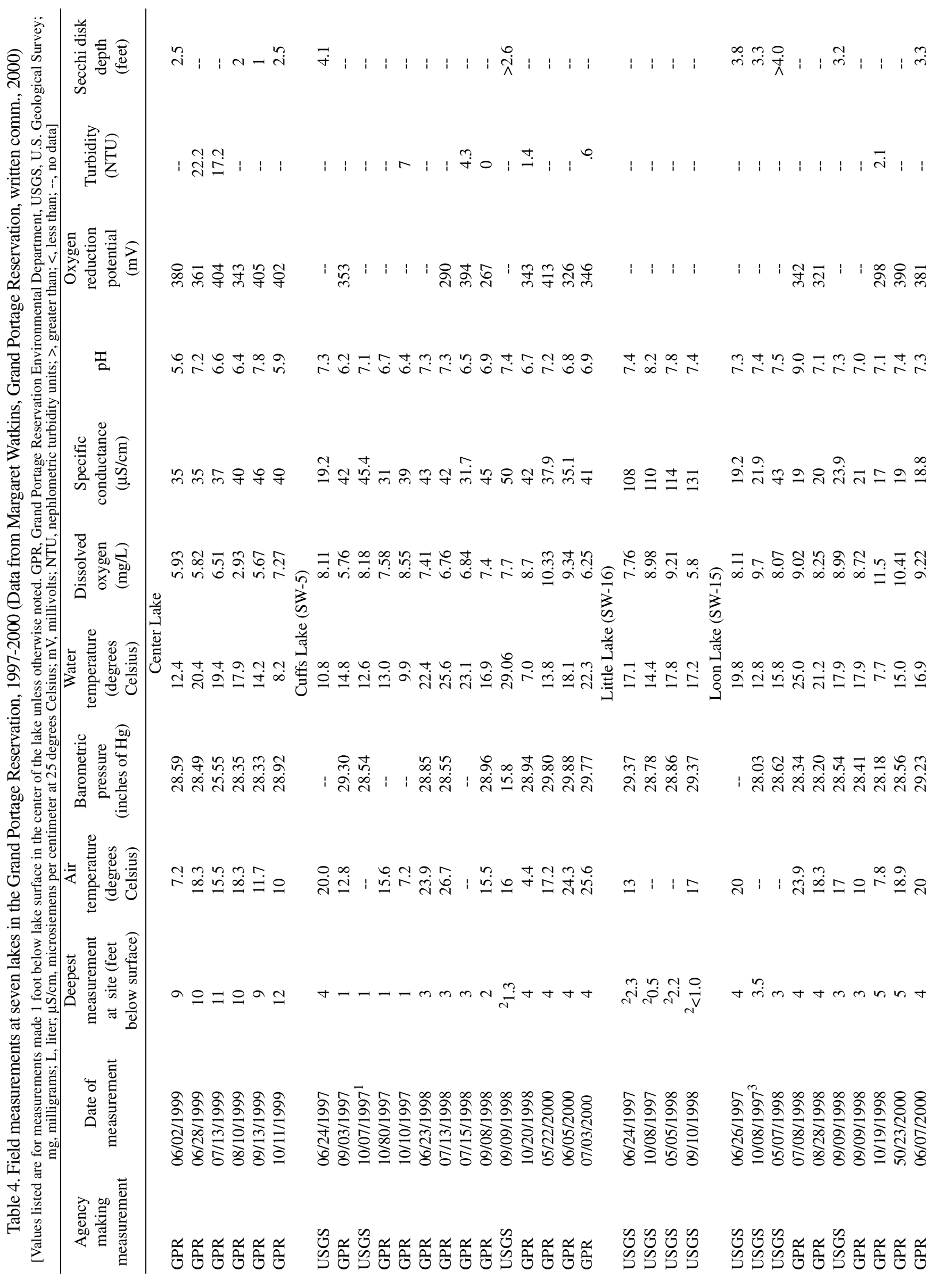




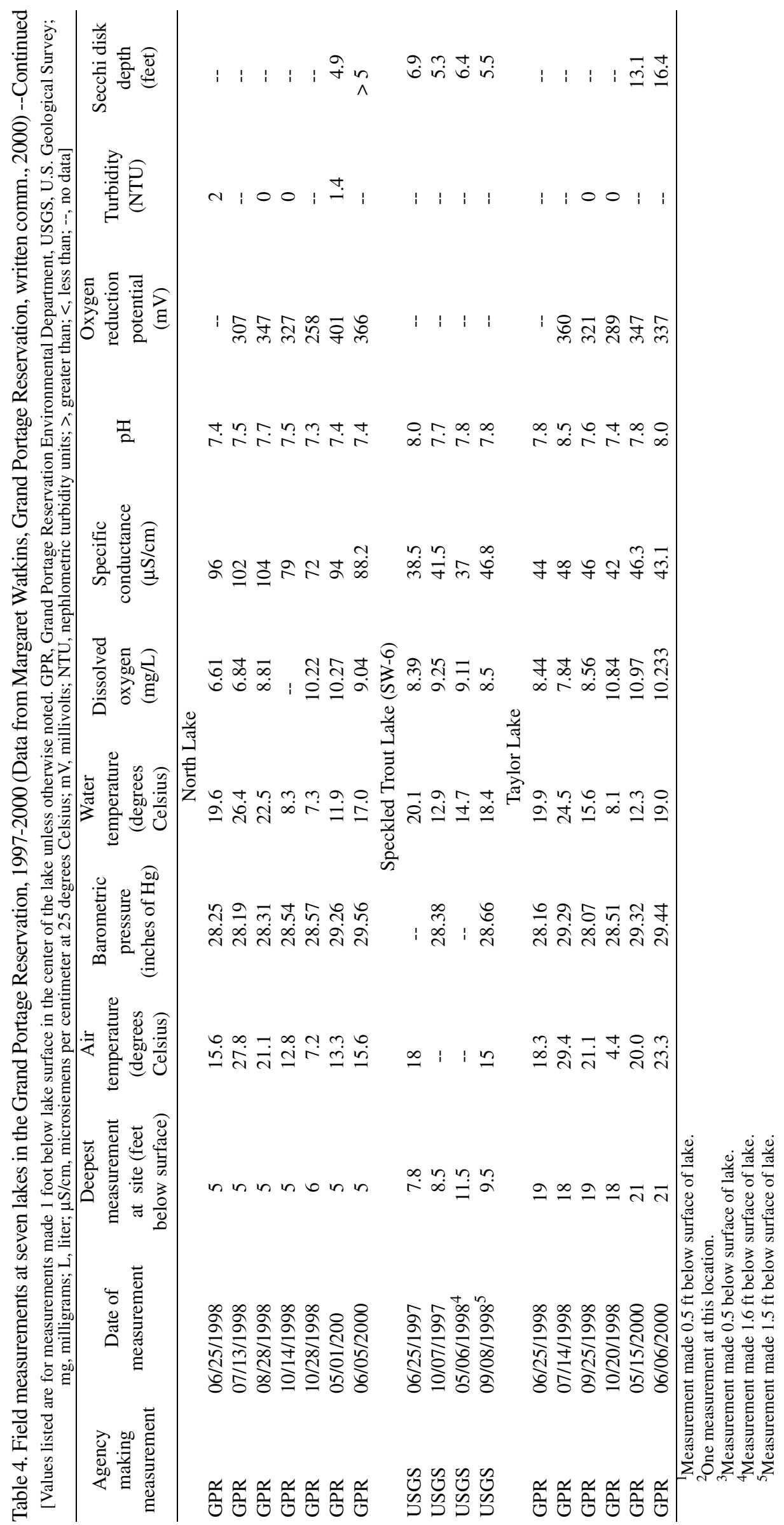




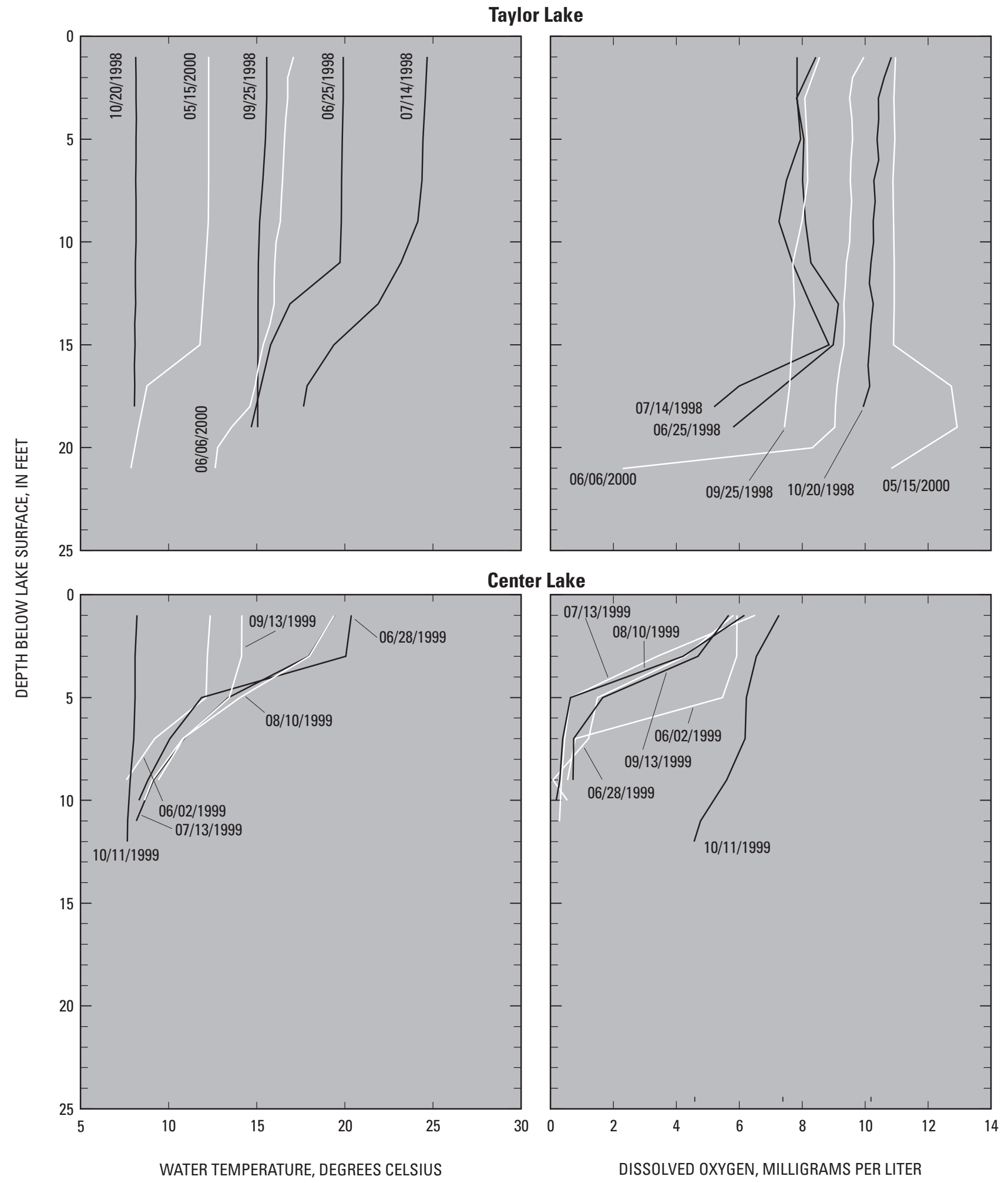

Figure 10. Temperature and dissolved oxygen profiles for Taylor and Center Lakes, Grand Portage Reservation, Minnesota, 1999-2000.

of sampling. Samples for two of the sites were determined to be contaminated and were not used. Recharge ages were determined for water from the other two sites (GW-9 and GW18); however, the ages may be incor- rect because of possible contamination. 
Table 5. U.S. Environmental Protection Agency drinking-water standards and health advisories

[Standards and health advisories from U.S. Environmental Protection Agency (2000). data from Rhul 1995, Ruhl, 1997, and Winterstein, 2000; mg/L, milligrams per liter; $\mu \mathrm{g} / \mathrm{L}$, micrograms per liter; <, less than; --, level or advisory not set]

\begin{tabular}{|c|c|c|c|c|c|c|}
\hline Constituent & Unit & $\begin{array}{c}\text { Maximum } \\
\text { contaminant level }\end{array}$ & $\begin{array}{l}\text { Secondary } \\
\text { drinking water } \\
\text { regulations }\end{array}$ & $\begin{array}{l}\text { Lifetime health } \\
\text { advisory }\end{array}$ & $\begin{array}{c}\text { Range of constituent } \\
\text { in sampled waters, } \\
1991-2000\end{array}$ & $\begin{array}{c}\text { Number of wells or sites } \\
\text { that exceeded levels or } \\
\text { advisory, 1991-2000 }\end{array}$ \\
\hline $\mathrm{pH}$ & & -- & $6.5-8.5$ & -- & $5.6-10.2$ & 9 wells \\
\hline Total dissolved solids & $\mathrm{mg} / \mathrm{L}$ & -- & 500 & -- & $58-3,110$ & 4 wells \\
\hline Aluminum & $\mathrm{mg} / \mathrm{L}$ & -- & $0.05-0.2$ & -- & $<0.01-0.398$ & 1 stream site \\
\hline Ammonia & $\mathrm{mg} / \mathrm{L}$ & -- & -- & 30 & $<0.015-0.074$ & 0 \\
\hline Antimony & $\mu \mathrm{g} / \mathrm{L}$ & 6 & -- & 6 & $<1-<1$ & 0 \\
\hline Arsenic & $\mu \mathrm{g} / \mathrm{L}$ & 50 & -- & -- & $<1-39$ & 0 \\
\hline Barium & $\mathrm{mg} / \mathrm{L}$ & 2 & -- & 2 & $<0.001-0.5$ & 0 \\
\hline Beryllium & $\mu \mathrm{g} / \mathrm{L}$ & 4 & -- & -- & $<2-<10$ & 0 \\
\hline Boron & $\mathrm{mg} / \mathrm{L}$ & -- & -- & 0.6 & $<0.01-0.736$ & 2 wells \\
\hline Chloride & $\mathrm{mg} / \mathrm{L}$ & -- & 250 & -- & $<.1-1,600$ & 6 wells \\
\hline Chromium (total) & $\mathrm{mg} / \mathrm{L}$ & 0.1 & -- & -- & $<0.001-0.002$ & 0 \\
\hline Copper & $\mathrm{mg} / \mathrm{L}$ & ${ }^{1} 1.3$ & 1.0 & -- & $0.001-0.01$ & 0 \\
\hline Fluoride & $\mathrm{mg} / \mathrm{L}$ & 4 & 2.0 & 4 & $<0.1-1.7$ & 0 \\
\hline Iron & $\mathrm{mg} / \mathrm{L}$ & -- & 0.3 & -- & $<0.01-2.86$ & 5 wells \\
\hline Manganese & $\mathrm{mg} / \mathrm{L}$ & -- & 0.05 & -- & $<0.004-0.21$ & 0 \\
\hline Mercury (inorganic) & $\mu \mathrm{g} / \mathrm{L}$ & 0.2 & -- & 0.2 & $<0.1-<0.1$ & 0 \\
\hline Molybdenum & $\mu \mathrm{g} / \mathrm{L}$ & -- & -- & 40 & $<1-<10$ & 0 \\
\hline Nickel & $\mathrm{mg} / \mathrm{L}$ & -- & -- & 0.1 & $<<0.001-0.002$ & 0 \\
\hline Nitrate & $\mathrm{mg} / \mathrm{L}$ as $\mathrm{N}$ & 10 & -- & -- & $<0.01-0.2$ & 0 \\
\hline Nitrite & $\mathrm{mg} / \mathrm{L}$ as $\mathrm{N}$ & 1 & -- & -- & $<0.01-0.042$ & 0 \\
\hline Nitrite plus nitrate & $\mathrm{mg} / \mathrm{Las} \mathrm{N}$ & 10 & -- & -- & $<0.01-0.32$ & 0 \\
\hline Selenium & $\mu \mathrm{g} / \mathrm{L}$ & 50 & -- & 50 & $<1-<1$ & 0 \\
\hline Silver & $\mathrm{mg} / \mathrm{L}$ & -- & 0.1 & -- & $<0.011-<0.001$ & 0 \\
\hline Strontium & $\mathrm{mg} / \mathrm{L}$ & -- & -- & 4 & $0.23-0.23$ & 0 \\
\hline Sulfate & $\mathrm{mg} / \mathrm{L}$ & -- & 250 & -- & $<0.1-194$ & 0 \\
\hline Zinc & $\mathrm{mg} / \mathrm{L}$ & -- & 5 & -- & $<0.003-0.260$ & 0 \\
\hline
\end{tabular}

${ }^{1}$ If this level is exceeded in over 10 percent of homes tested, treatment to reduce this level is initiated.

\section{RECHARGE AGES OF SAMPLED WATER}

Tritium and $\mathrm{SF}_{6}$ dating techniques indicate the mean residence time (recharge age) of water in an aquifer, but more information is needed to determine the recharge age of the water. The assumption in dating ground water by these methods is that precipitation percolates into the aquifer and th4en travels as a plug in a well-defined path to the well or spring. In actuality, water sampled from an aquifer often contains water from several years precipitation (Clark and Fritz, 1997). Ground water from several sources can mix as it moves through the ground or bedrock. Finally, the wells sampled in the Grand Portage Reservation are not cased in the bedrock and are open to the entire bedrock (table 3). As a result, the water in the wells may be a mixture of young and old water from different bedrock aquifers.

Tritium concentrations of two of the samples, GW-6 and GW-20, were less than the detection limit. The water in these samples was from precipitation that fell before 1953. The water in the other 10 tritium samples could have come from precipitation that fell between 1953 and 1962, or after 1970 , or be a mixture of old and young water (fig. 11). The recharge age of water in SP-8 and GW-22 is probably 1997 or later. SP-8 is a seep on the side of a hill, and the water in the spring probably comes from shallow ground water. Well GW-22 is shallow, about $47 \mathrm{ft}$ deep, and the ionic concentrations in the sampled water resemble those from surface water or springs (figs. 7-9). In addition to being analyzed for tritium, one well and two springs were sampled for $\mathrm{SF}_{6}$ during fall 2000. The $\mathrm{SF}_{6}$ dating places the age of these samples after 1983 (table 7, fig. 11). Therefore, it is probable that the remaining five tritium samples were composed of 


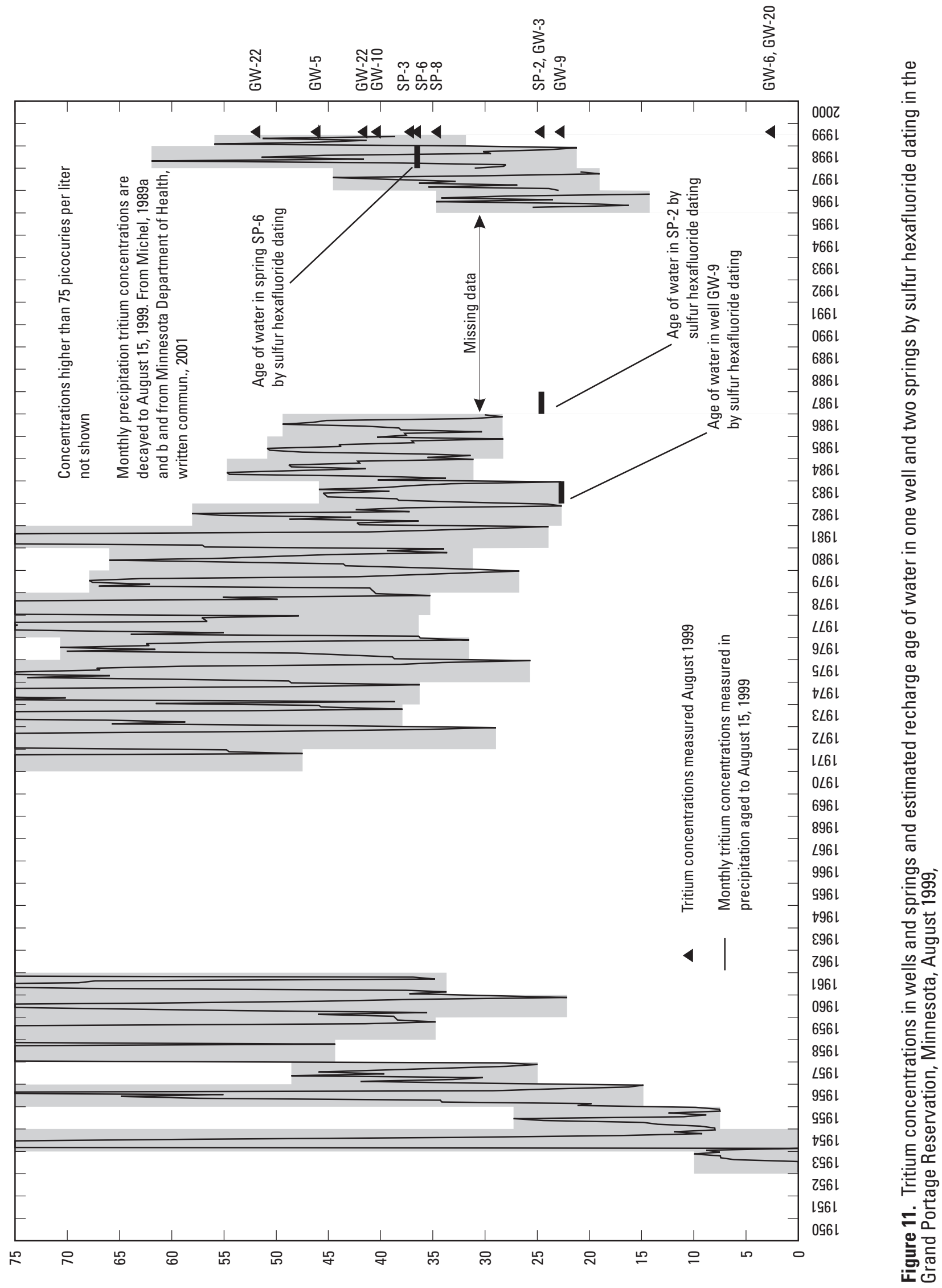

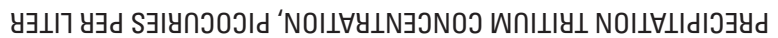


precipitation that fell after 1970.

$\mathrm{SF}_{6}$ dating placed the recharge dates of water from four wells (GW1, GW-9, GW-15, and GW-18) between 1973 and 1998 and the recharge dates of water from three springs (SP-2, SP-5, and SP-6) between 1987 and 1998.

The age dating done for this study can be used, along with other factors, to determine the source of water in two wells. The water in wells GW-6 and GW-20 (fig. 1) is from the regional ground-water system, considering that the water is older than 1953, based on tritium dating. The water in GW-1 may also be from the same regional system based upon its age, 1973, from $\mathrm{SF}_{6}$ dating. As noted earlier, the water in GW-22 was precipitation 1998 or later; the water in this well is probably from shallow ground water. Springs SP-5, SP-6, and SP-8 have water younger than 1997. Therefore, they are probably discharge points for shallow ground water.

Table 6. Tritium data collected from wells and springs in the Grand Portage Reservation, Minnesota, August 16-24, 1999

$[\mathrm{pCi} / \mathrm{L}$, picocuries per liter; <, less than $\}$

\begin{tabular}{|c|c|c|c|c|}
\hline $\begin{array}{c}\text { Map } \\
\text { number }\end{array}$ & Station number & Station Name & $\begin{array}{l}\text { Tritium } \\
(\mathrm{pCi} / \mathrm{L})\end{array}$ & $\begin{array}{l}\text { Accuracy of analysis } \\
\text { (plus or minus pCi/L) }\end{array}$ \\
\hline GW-3 & 475237089515501 & Evans, Grand Portage Reservation & 24.6 & 2.6 \\
\hline GW-5 & 475341089472301 & Long, Grand Portage Reservation & 46.1 & 3.5 \\
\hline GW-6 & 475431089461601 & Sawmill, Grand Portage Reservation & $<2.6$ & 1.6 \\
\hline GW-9 & 475508089444101 & Johnson, Grand Portage Reservation & 22.7 & 2.2 \\
\hline GW-10 & 475549089430201 & Paro, Grand Portage Reservation & 40.3 & 3.2 \\
\hline GW-20 & 480001089353401 & Pigeon River State Park & $<2.6$ & 1.6 \\
\hline GW-22 & 480035089424201 & Hart, Grand Portage Reservation & 41.6 & 3.2 \\
\hline GW-22 & 480035089424201 & Hart, Grand Portage Reservation & 51.8 & 4.2 \\
\hline SP-2 & 475700089460001 & Spring 3, Grand Portage Reservation & 24.6 & 2.2 \\
\hline SP-3 & 475700089500001 & Spring 1, Grand Portage Reservation & 37.1 & 2.9 \\
\hline SP-6 & 475000089400002 & Spring 2, Grand Portage Reservation & 36.5 & 2.9 \\
\hline SP-8 & 475800089470001 & Spring 7, Grand Portage Reservation & 34.6 & 2.9 \\
\hline
\end{tabular}

Table 7. Estimated recharge age of water by sulfur hexafluoride analysis in wells and springs in the Grand Portage Reservation, Minnesota, sampled August and October 2000

[Two samples were taken at each site and analyzed]

\begin{tabular}{lllc}
\hline \multicolumn{1}{c}{ Site No. } & Station Number & \multicolumn{1}{c}{ Station Name } & $\begin{array}{c}\text { Year water was } \\
\text { precipitation }\end{array}$ \\
\hline GW-1 & 475229089520601 & Olson, Grand Portage Reservation & 1973.5 \\
GW-1 & 475229089520601 & Olson, Grand Portage Reservation & 1973 \\
GW-9 & 475508089444101 & Johnson, Grand Portage Reservation & 1983.5 \\
GW-9 & 475508089444101 & Johnson, Grand Portage Reservation & 1983 \\
GW-15 & 475719089465201 & T63NR5E03CCC & 1989.5 \\
GW-15 & 475719089465201 & T63NR5E03CCC & 1989.5 \\
GW-18 & 475821089415301 & Land fill, Grand Portage Reservation & 1997.5 \\
GW-18 & 475821089415301 & Land fill, Grand Portage Reservation & 1998 \\
SP-2 & 475700089460001 & Spring 3, Grand Portage Reservation & Contaminated \\
SP-2 & 475700089460001 & Spring 3, Grand Portage Reservation & Contaminated \\
SP-2 & 475700089460001 & Spring 3, Grand Portage Reservation & 1987 \\
SP-2 & 475700089460001 & Spring 3, Grand Portage Reservation & 1987 \\
SP-4 & 475700089500002 & Spring 4, Grand Portage Reservation & Contaminated \\
SP-4 & 475700089500002 & Spring 4, Grand Portage Reservation & Contaminated \\
SP-5 & 475800089400002 & Spring 9, Grand Portage Reservation & 1997 \\
SP-5 & 475800089400002 & Spring 9, Grand Portage Reservation & 1997 \\
SP-6 & 475800089400002 & Spring 3, Grand Portage Reservation & 1998 \\
SP-6 & 475800089400002 & Spring 3, Grand Portage Reservation & 1998 \\
\hline
\end{tabular}




\section{SUMMARY}

The Grand Portage Reservation is located in northeastern Cook County, Minnesota at the boundary between Minnesota, USA, and Ontario, Canada. Between 1991 and 2000 the U.S. Geological Survey (USGS) conducted a series of studies, in cooperation with the Grand Portage Band of Chippewa, to describe the water resources of the Grand Portage Reservation.

Ground water moves primarily through fractures in the bedrock. The local ground-water system probably follows the surface topography, flows through the thin unconsolidated material and shallow bedrock fractures and discharges to wetlands, seeps, springs, and nearby lakes and streams. The regional ground-water flow system probably discharges into regional lows such as the Lake Superior, Pigeon River, and other streams and lakes. The deep ground-water flow system probably flows from the interior of Minnesota and Canada and discharges into Lake Superior. Lake Superior maybe the discharge point for brines in the deep ground-water flow system.

The watersheds of the streams in the Grand Portage Reservation are small and stream slopes are steep; the streams in the Grand Portage Reservation tend to be flashy. The percent of rainfall at the Grand Portage Ranger Station that become runoff in these watersheds is about 45 percent.

The lake stages of Loon and Cuffs Lakes were continuously measured during the ice free part of the year from June 1998 through November 2000. The lake stages rise and fall with rainfall.

The $\mathrm{pH}$ of water in the Reservation is generally alkaline $(\mathrm{pH}$ greater than 7.0). The alkalinity of water in the Reservation is low, less than $100 \mathrm{mg} / \mathrm{L}$ as $\mathrm{CaCO}_{3}$. The concentrations of major ions are much greater in ground water than in spring water and surface water.

Water from 11 of the 20 wells sampled are a calciumsodium-chloride type. Water from GW-2, GW-7, and GW11 had much greater specific conductance concentrations of major ions compared to the other wells. The greater concentrations of calcium, sodium, and chloride in these wells may be from the dissolution of the rock matrix, or the upward discharge of brines from the underlying Precambrian rocks.

Some spring water (SP-1, SP-3, SP-4, SP-6, and SP-8) is calcium-bicarbonate type like surface water, whereas other spring water (SP-5 and SP-7) is similar to the calcium-sodium-chloride type occurring in samples from about one-half the wells.

The major chemical constituents in surface water are bicarbonate, calcium, and magnesium. Water samples from lakes show almost no seasonal variation in ionic concentrations, whereas water samples taken from streams show seasonal variation (SW-1 and SW-10). The concentrations of the calcium cation and bicarbonate and carbonate anions increase in streams during periods of low.

The water in selected wells and springs were analyzed to determine the recharge age. The tritium concentrations were measured in eight wells and four springs of the Grand Portage Reservation during August 1999. Sulfur hexafluoride $\left(\mathrm{SF}_{6}\right)$ concentrations were determined in water sampled from four wells and four springs during August and October 2000. The tritium and $\mathrm{SF}_{6}$ concentrations were used to determine the recharge age of the sampled water. The recharge ages of two of the wells sampled for tritium, GW-6 and GW-20, are before 1953. The recharge ages of the remaining 10 samples for tritium are probably after 1970. The recharge ages of seven $\mathrm{SF}_{6}$ samples were between 1973 and 1998.

\section{REFERENCES}

Baker, D.G., and Kuehnast, E.L., 1978, Climate of Minnesota, Part $X$. Precipitation normals for Minnesota-1941-1970: University of Minnesota Agricultural Experiment Station Technical Bulletin $314,15 \mathrm{p}$.

Baker, D.G., Kuenhast, E.L., and Zandlo, J.A., 1985, Climate of Minnesota: Part XV. Normal temperatures (1951-1980) and their application: University of Minnesota Agricultural Experiment Station Technical Bulletin AD-SB 2777, 66 p.

Busenberg, E., and Plummer, N.L., 1997, Use of sulfur hexafluoride as a dating tool and as a tracer of igneous and volcanic fluids in ground water: Geological Society of America, Salt lake City, 1997, Abstracts and Programs, v. 29, no. 6, p. A-78.

Busenberg, E., and Plummer, N.L., 2000 , Dating young groundwater with sulfur hexafluoride-Natural and anthropogenic sources of sulfur hexafluoride: Water Resources Research, v. 36, no. 10, p. 30113030.

Clark, I.D., and Fritz, P., 1997, Environmental isotopes in hydrogeology: Boca Raton, Florida, Lewis Publishers, Inc., 352 p.

Green, J.C., 1982, Geologic map of Minnesota, Two Harbors sheet, bedrock geology: Minnesota Geological Survey, scale 1:250,000. Hem, J.D., 1992, Study and interpre- 
tation of the chemical characteristics of natural water, $3^{\text {rd }}$ edition: U.S. Geological Survey WaterSupply Paper 2254, 263 p., 2 pl.

International Atomic Energy Agency/World Meteorological Organization, 1998, Global network for isotopes in precipitation. The GNIP data base. Release 3, October 1999: URL:

http://www.iaea.org/programs/ri/gnip/gnipmain.htm (accessed January 2002).

Kelly, W.C., Rye, R.O., and Livnat, A., 1986, Saline mine waters of the Keweenaw Peninsula, northern Michigan-Their nature, origin, and relation to similar deep waters in Precambrian crystalline rocks of the Canadian shield: American Journal of Science, v. 286, p. 281308.

Michel, R.L., 1989a, Tritium deposition over the continental United States, 1953-1983, in Atmospheric deposition: International Association of Hydrological Sciences, Oxfordshire, United Kingdom, p. 109-115.

1989b, Tritium deposition in the continental United States, 1953-1983: U.S. Geological Survey Water-Resources Investigations Report 89-4072, 46 p.

Omernik, J.M., 1987, Ecoregions of the conterminous United States: Annals of the Association of
American Geographers, v. 77, p. 118-125.

Paillet, F.L., and Olson, J.D., 1994, Analysis of the results of hydraulic-fracture stimulation of two crystalline bedrock boreholes, Grand Portage, Minnesota: U.S. Geological Survey WaterResources Investigations Report 94-4044, $45 \mathrm{p}$.

Ruhl, J.F., 1995, Water resources of the Grand Portage Indian Reservation, northeastern Minnesota: U.S. Geological Survey WaterResources Investigations Report 94-4199, 28 p.

1997, Physical and chemical properties of water and sediments, Grand Portage and Wauswaugoning Bays, Lake Superior, Grand Portage Indian Reservation, northeastern Minnesota, 1993-96: U.S. Geological Survey Water-

Resources Investigations Report 97-1999, 13 p.

Shepard Miller, Inc., 1995, Environmental aspects of the proposed solution mining operation at the White Pine Mine, White Pine, Michigan - vol. 1. Text: Prepared for the Copper Range Co., White Pine, Michigan, unpaged.

U.S. Army Corps of Engineers, 1999, Tracer dye tests work planFormer Finland Air Force Station (FFAS), Lake County, Minnesota: U.S. Army Corps of Engineers,
Omaha District, USACE Contract No. DACW45-94-0044, unpaged.

U.S. Environmental Protection Agency, 2000, Drinking standards and health advisories: United States Environmental Protection Agency, Office of Water, EPA 822-8-00-001, 12 p.

Wilde, F.D., and Radtke, D.B., eds., 1998, Field measurements: U.S. Geological Survey Handbooks for Water-Resources Investigations, book 9, chap. A6, unpaged.

Wilde, F.D., Radtke, D.B., Gibs, J., and Iwatsubo, R.T., eds., 1999a, Collection of water samples: U.S. Geological Survey Handbooks for Water-Resources Investigations, book 9, chap. A4, unpaged. 1999b, Processing of water samples: U.S. Geological Survey Handbooks for Water-Resources Investigations, book 9, chap. A5, unpaged.

Winterstein, T.A., 2000, Water-quality data from lakes and streams in the Grand Portage Reservation, Minnesota, 1997-98: U.S. Geological Survey Open-File Report 00364, $16 \mathrm{p}$.

Wyrick, G.G., and Borchers, J.W., 1981, Hydrologic effects of stressrelief fracturing in an Appalachian valley: U.S. Geological Survey Water-Supply Paper 2177, 51 p. 


\section{SUPPLEMENTAL INFORMATION}




\section{WATER-QUALITY DATA COLLECTED DURING 1999 AND 2000}

Water samples were collected from 11 wells in the Grand Portage Reservation during August 1999 (fig. 1; table S-1). Water was pumped from the wells until specific conductance, $\mathrm{pH}$, and dissolved oxygen readings became constant. The samples were then collected and preserved in accordance with procedures in Wilde and others (1999a; 1999b). The samples were analyzed at the USGS National Water Quality Laboratory (NWQL) in Arvada, Colorado, for major ions, nutrients, and trace metals.

Water samples were collected from eight springs in the Grand Portage Reservation in August 1999 (fig. 1; table S-2). The locations of the springs are reported only to the nearest minute (table 1); the springs are located within the circles shown in figure 1 . The samples were collected by pushing a small sand-point well screen (2 in. in diameter) into the ground at the source of the spring. Water was pumped from inside the sand-point with a peristaltic pump until specific conductance, $\mathrm{pH}$, and dissolved oxygen readings became constant. The samples were then collected and preserved in accordance with procedures in Wilde and others (1999a; 1999b). The samples were analyzed at the NWQL in Arvada, Colorado, for major ions, nutrients, and trace metals.

Field measurements (specific conductance, $\mathrm{pH}$, temperature, and dissolved oxygen) were made in accordance with procedures described in Wilde and Radtke (1998). The measurements were made with a portable, multiparameter meter calibrated at the start of each sampling day. Alkalinity was determined in the field by incremental titration of filtered samples.

Two quality-assurance samples were collected (table S-3). One replicate sample was collected from well GW-4. One field blank was collected before sampling at the Pigeon River State Park well, GW-20.

Replicate samples are collected to assess the quality, reliability, and precision (reproducibility) of the data generated by the analysis of the samples for chemical constituents. The difference between the values for the sample and the replicate sample are shown in table S-4. The percent difference was calculated as:

$$
\frac{X_{1}-X_{2}}{X_{1}+X_{2}} \times 100
$$

where $X_{1}$ is the value for the sample, and

$\mathrm{X}_{2}$ is the value for the replicate sample.

The percent difference was less than 10 except for total ammonia plus organic nitrogen and for dissolved zinc.

The field blank was collected by passing inorganic-free, de-ionized water through all sample equipment contacted by the actual sample. Field blanks are collected to ensure that equipment cleaning between sampling sites remove all contamination from the previous site, that sampling and sample-processing procedures do not contaminate the equipment, and that transporting and handling the sampling equipment between sites does not contaminate the equipment. The concentrations of analyzed constituents in the field blank were below the detection limit or near the detection limit.

Water samples were collected from four springs and seven wells in 1999 (table 1) and analyzed for tritium. The samples were collected in accordance with procedures specified by the analyzing laboratory, the Environmental Isotope Laboratory, University of Waterloo, Ontario, Canada (EIL) (Environmental Isotope Laboratory, written commun., Aug. 13, 1999). The samples were analyzed at EIL for enriched tritium. The results of the analysis for the tritium concentrations are in table 6.

Water samples were collected from four wells and four springs August-October 2000 (table 1) and analyzed for sulfur hexafluoride $\left(\mathrm{SF}_{6}\right)$. The samples were collected in accordance with procedures specified by the analyzing laboratories, the Reston Dissolved Gas Laboratory and the Reston $\mathrm{SF}_{6}$ Laboratory, U.S. Geological Survey, Reston, Virginia. The samples were analyzed for concentrations of dissolved gases and SF6 and the results were used to date the recharge age of the sampled water (table 7) . 


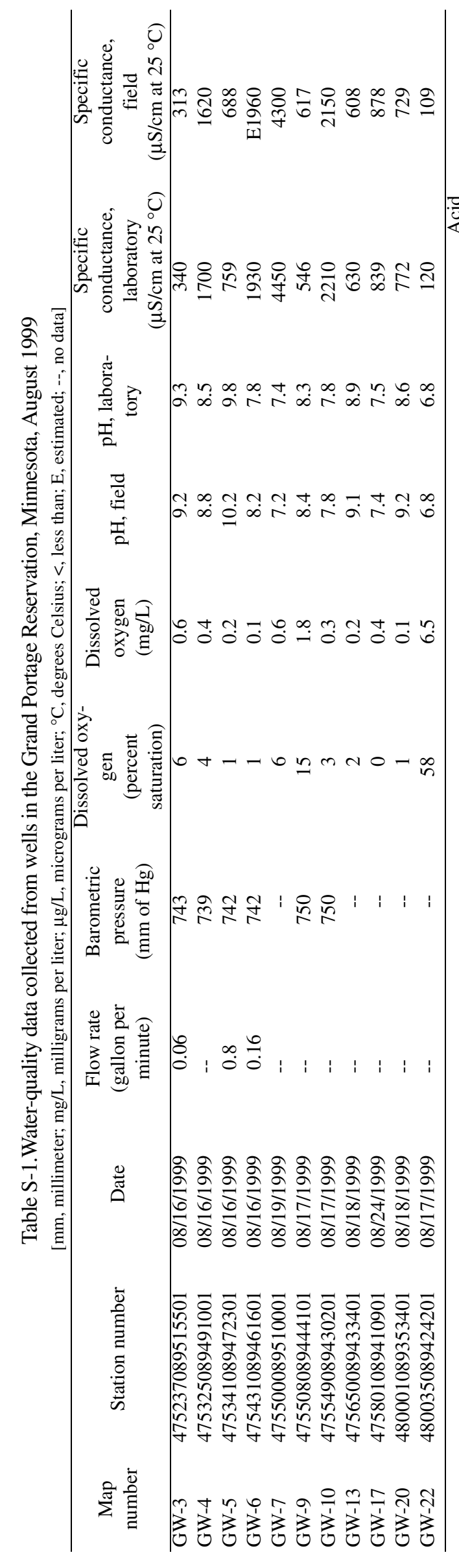

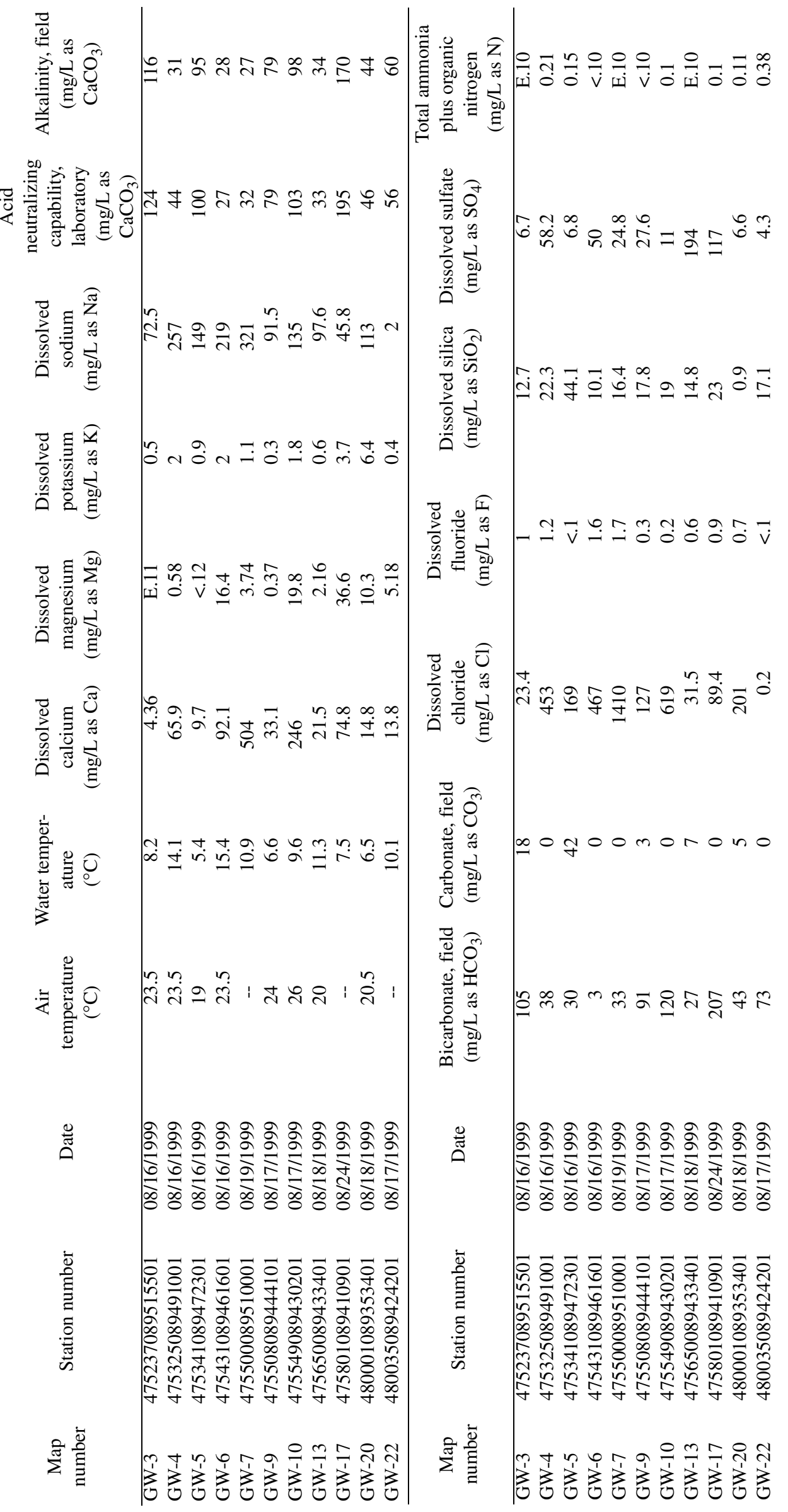




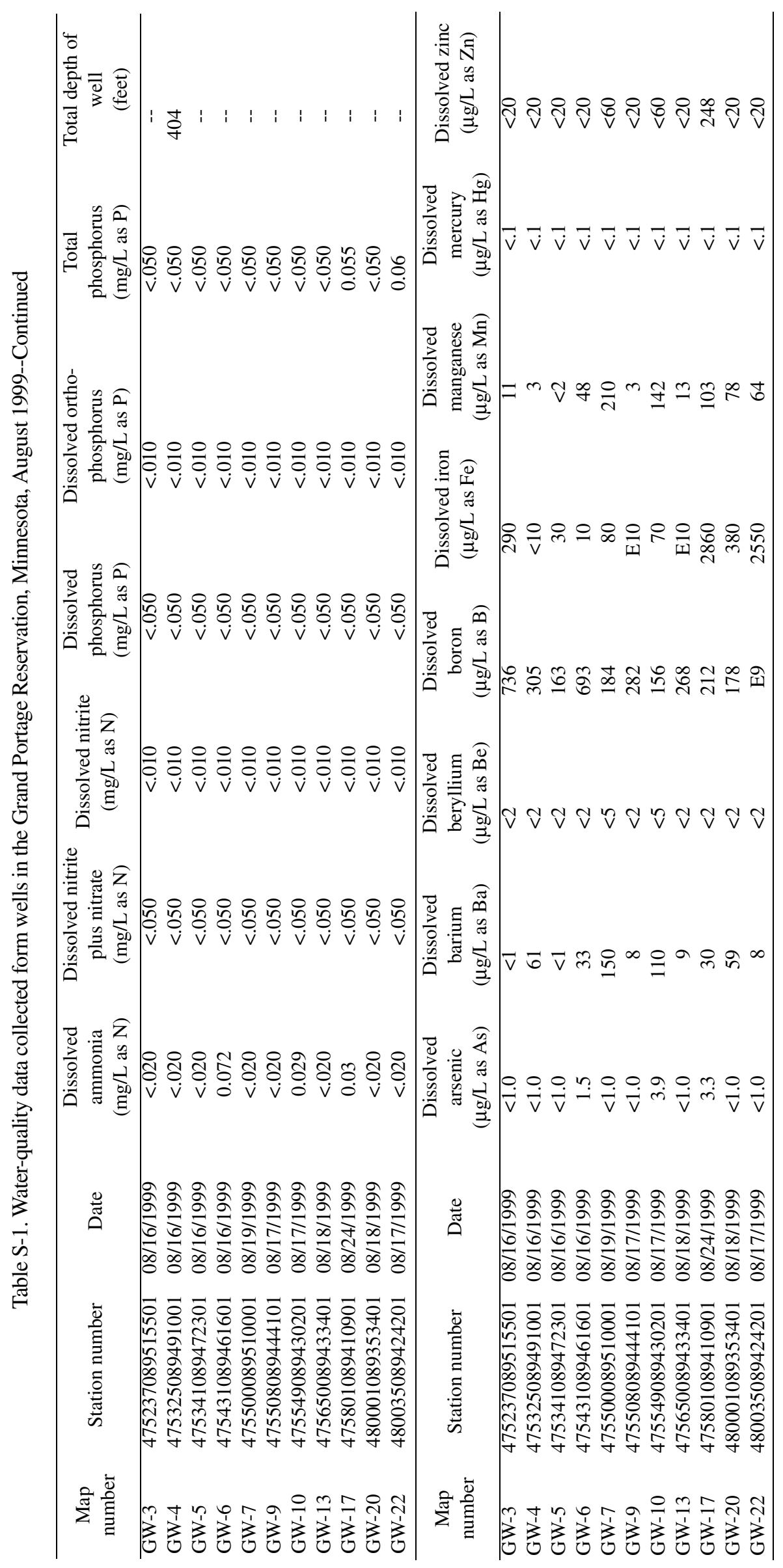


Table S-2. Water-quality data collected from springs in the Grand Portage Reservation, Minnesota, 1999

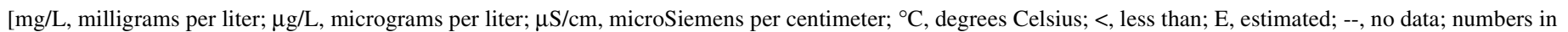

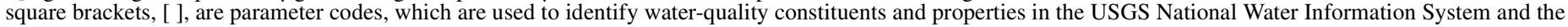
U.S. Environmental Protection Agency Data Storage and Retrieval System]

\begin{tabular}{cclrrr}
\hline $\begin{array}{c}\text { Map } \\
\text { number }\end{array}$ & Station number & \multicolumn{1}{c}{ Station name } & Date & $\begin{array}{c}\text { Barometric pressure } \\
\text { (mm of Hg) [25] }\end{array}$ & $\begin{array}{c}\text { Dissolved oxygen } \\
\text { (percent saturation) [301\} }\end{array}$ \\
\hline SP-1 & 475400089470001 & Spring 10, Grand Portage Reservation & $08-24-99$ & -- & 13 \\
SP-2 & 475700089460001 & Spring 3, Grand Portage Reservation & $08-24-99$ & -- & 35 \\
SP-3 & 475700089500001 & Spring 1, Grand Portage Reservation & $08-19-99$ & -- & 73 \\
SP-4 & 475700089500002 & Spring 4, Grand Portage Reservation & $08-19-99$ & 731 & 30 \\
SP-5 & 475800089400002 & Spring 9, Grand Portage Reservation & $08-24-99$ & -- & 46 \\
SP-6 & 475800089400002 & Spring 2, Grand Portage Reservation & $08-24-99$ & -- & -17 \\
SP-7 & 475800089410002 & Spring 14, Grand Portage Reservation & $08-25-99$ & -- & 60 \\
SP-8 & 475800089470001 & Spring 7, Grand Portage Reservation & $08-17-99$ & 731 & \\
\hline
\end{tabular}

\begin{tabular}{|c|c|c|c|c|c|c|c|}
\hline $\begin{array}{c}\text { Map } \\
\text { number }\end{array}$ & Station number & Date & $\begin{array}{c}\text { Dissolved } \\
\text { oxygen } \\
(\mathrm{mg} / \mathrm{L})[300\}\end{array}$ & $\begin{array}{c}\mathrm{pH}, \text { whole water, } \mathrm{pH}, \mathrm{v} \\
\text { field } \\
\text { (standard units) } \\
\text { (star } \\
{[400]}\end{array}$ & $\begin{array}{l}\text { whole water, Speci } \\
\text { aboratory } \\
\text { ndard units) } \\
{[403]}\end{array}$ & $\begin{array}{l}\text { cific conductance, } \\
\text { laboratory } \\
\left.\text { S/cm at } 25^{\circ} \mathrm{C}\right) \\
{[90095]}\end{array}$ & $\begin{array}{l}\text { Specific conductance, } \\
\text { field } \\
\left(\mu \mathrm{S} / \mathrm{cm} \text { at } 25^{\circ} \mathrm{C}\right)[95]\end{array}$ \\
\hline SP-1 & 475400089470001 & $08-24-99$ & 1.3 & 5.7 & 6.0 & 58 & 50 \\
\hline SP-2 & 475700089460001 & 08-24-99 & 4.2 & 8.6 & 8.6 & 138 & 123 \\
\hline SP-3 & 475700089500001 & 08-19-99 & 7.9 & 7.1 & 7.5 & 136 & 124 \\
\hline SP-4 & 475700089500002 & 08-19-99 & 2.9 & 6.3 & 7.0 & 145 & 132 \\
\hline SP-5 & 475800089400002 & 08-24-99 & 4.9 & 6.2 & 6.5 & 262 & 252 \\
\hline SP-6 & 475800089400002 & 08-24-99 & 4.9 & 6.4 & 6.8 & 125 & 112 \\
\hline SP-7 & 475800089410002 & $08-25-99$ & 7.4 & 7.4 & 7.4 & 188 & 181 \\
\hline SP-8 & 475800089470001 & 08-17-99 & 7.0 & 7.1 & 6.7 & 102 & 84 \\
\hline $\begin{array}{c}\text { Map } \\
\text { number }\end{array}$ & Station number & Date & $\begin{array}{c}\text { Air } \\
\text { temperature } \\
\left({ }^{\circ} \mathrm{C}\right)[20]\end{array}$ & $\begin{array}{l}\text { Water temperature } \\
\quad\left({ }^{\circ} \mathrm{C}\right)[10]\end{array}$ & $\begin{array}{c}\text { Dissolved calciun } \\
(\mathrm{mg} / \mathrm{L} \text { as } \mathrm{Ca}) \\
{[915]}\end{array}$ & $\begin{array}{c}\text { Dissolved } \\
\text { magnesium } \\
(\mathrm{mg} / \mathrm{L} \text { as } \mathrm{Mg}) \\
{[925]}\end{array}$ & $\begin{array}{c}\text { Dissolved } \\
\text { potassium } \\
(\mathrm{mg} / \mathrm{L} \text { as } \mathrm{K})[935]\end{array}$ \\
\hline$\overline{\text { SP-1 }}$ & 400089470001 & $08-24-99$ & -- & 15.1 & 5.95 & 2.58 & .3 \\
\hline SP-2 & 700089460001 & $08-24-99$ & -- & 6.6 & 14.5 & 1.94 & .3 \\
\hline SP-3 & 700089500001 & 08-19-99 & 29.0 & 9.6 & 20.7 & 3.64 & .1 \\
\hline SP-4 & 700089500002 & $08-19-99$ & 29.0 & 15.6 & 17.8 & 5.95 & .3 \\
\hline SP-5 & 800089400002 & 08-24-99 & -- & 11.5 & 17.7 & 6.51 & .9 \\
\hline SP-6 & 800089400004 & 08-24-99 & -- & 10.3 & 12.1 & 3.87 & .6 \\
\hline SP-7 & 800089410002 & $08-25-99$ & -- & 16.1 & 14.5 & 5.12 & .6 \\
\hline SP-8 & 800089470001 & 08-17-99 & 24.5 & 8.2 & 12.6 & 3.94 & .3 \\
\hline $\begin{array}{c}\text { Map } \\
\text { number }\end{array}$ & Station number & Date & $\begin{array}{c}\text { Dissolved sodium } \\
\text { (mg/L as Na) } \\
{[930]}\end{array}$ & $\begin{array}{c}\text { Acid neutralizing } \\
\text { capability } \\
\text { laboratory } \\
\left(\mathrm{mg} / \mathrm{L} \text { as } \mathrm{CaCO}_{3}\right) \\
{[90410]}\end{array}$ & $\begin{array}{c}\text { Alkalinity, filtered } \\
\text { water, field } \\
\left(\mathrm{mg} / \mathrm{L} \text { as } \mathrm{CaCO}_{3}\right) \\
{[39086\}}\end{array}$ & $\begin{array}{c}\text { Bicarbonate, } \\
\text { filtered water, field } \\
\left(\mathrm{mg} / \mathrm{L} \text { as } \mathrm{HCO}_{3}\right) \\
{[453]}\end{array}$ & $\begin{array}{l}\text { Carbonate, filtered } \\
\text { water, field } \\
\left(\mathrm{mg} / \mathrm{L} \text { as } \mathrm{CO}_{3}\right) \\
{[452]}\end{array}$ \\
\hline SP-1 & 400089470001 & $08-24-99$ & 1.7 & 18 & 17 & 21 & 0 \\
\hline SP-2 & 700089460001 & $08-24-99$ & 12.8 & 65 & 52 & 63 & 0 \\
\hline SP-3 & 700089500001 & 08-19-99 & 1.5 & 64 & 61 & 74 & 0 \\
\hline SP-4 & 700089500002 & 08-19-99 & 1.6 & 67 & 61 & 74 & 0 \\
\hline SP-5 & 800089400002 & 08-24-99 & 23.1 & 53 & 46 & 56 & 0 \\
\hline SP-6 & 800089400004 & 08-24-99 & 7.4 & 45 & 39 & 48 & 0 \\
\hline SP-7 & 800089410002 & $08-25-99$ & 15.9 & 56 & 49 & 60 & 0 \\
\hline SP-8 & 800089470001 & $08-17-99$ & 1.7 & 45 & 40 & 48 & 0 \\
\hline
\end{tabular}


Table S-2. Water-quality data collected from springs in the Grand Portage Reservation, Minnesota, 1999--Continued

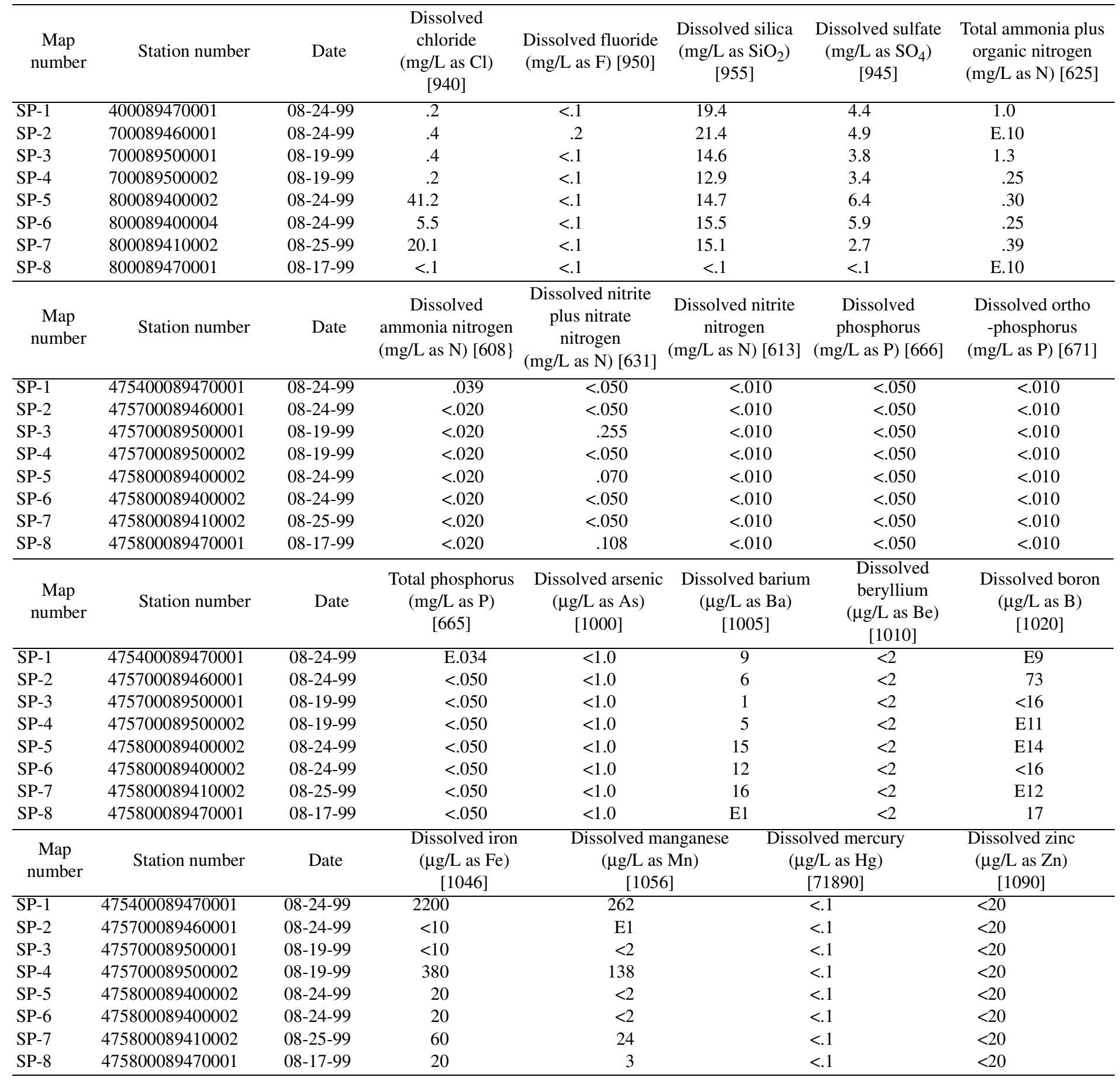


Table S-3. Quality-assurance samples from the Grand Portage Reservation, Minnesota, August 1999

[mg/L, milligrams per liter; $\mu \mathrm{g} / \mathrm{L}$, micrograms per liter; ${ }^{\circ} \mathrm{C}$, degrees Celsius; <, less than; E, estimated; --, no data]

\begin{tabular}{|c|c|c|}
\hline Constituent & $\begin{array}{l}\text { Replicate Sample } \\
\text { Well GW-4, } \\
475325089491001\end{array}$ & $\begin{array}{c}\text { Field Blank } \\
\text { Well GW-20, } \\
480001089353401\end{array}$ \\
\hline Dissolved calcium (mg/L as Ca) & 68.4 & $<.02$ \\
\hline Dissolved magnesium (mg/L as $\mathrm{Mg}$ ) & 0.6 & $<.12$ \\
\hline Dissolved potassium (mg/L as $\mathrm{K}$ ) & 2.0 & $<.1$ \\
\hline Dissolved sodium (mg/L as $\mathrm{Na})$ & 258 & $<.1$ \\
\hline Acid neutralizing capability, laboratory $\left(\mathrm{mg} / \mathrm{L}\right.$ as $\left.\mathrm{CaCO}_{3}\right)$ & 37 & 2 \\
\hline Alkalinity, filtered water, field $\left(\mathrm{mg} / \mathrm{L}\right.$ as $\left.\mathrm{CaCO}_{3}\right)$ & 31 & -- \\
\hline Bicarbonate, filtered water, field $\left(\mathrm{mg} / \mathrm{L}\right.$ as $\left.\mathrm{HCO}_{3}\right)$ & 28 & -- \\
\hline Carbonate, filtered water, field $\left(\mathrm{mg} / \mathrm{L}\right.$ as $\left.\mathrm{CO}_{3}\right)$ & 5 & -- \\
\hline Dissolved chloride $(\mathrm{mg} / \mathrm{L}$ as $\mathrm{Cl})$ & 452 & $<.1$ \\
\hline Dissolved fluoride (mg/L as F) & 1.3 & $<.1$ \\
\hline Dissolved silica $\left(\mathrm{mg} / \mathrm{L}\right.$ as $\left.\mathrm{SiO}_{2}\right)$ & 22.2 & $<.1$ \\
\hline Dissolved sulfate $\left(\mathrm{mg} / \mathrm{L}\right.$ as $\left.\mathrm{SO}_{4}\right)$ & 58.6 & $<.1$ \\
\hline Total ammonia plus organic nitrogen $(\mathrm{mg} / \mathrm{L}$ as $\mathrm{N})$ & 0.1 & E. 10 \\
\hline Dissolved ammonia nitrogen (mg/L as N) & $<.020$ & $<.020$ \\
\hline Dissolved nitrite plus nitrate nitrogen $(\mathrm{mg} / \mathrm{L}$ as $\mathrm{N})$ & $<.050$ & $<.050$ \\
\hline Dissolved nitrite nitrogen (mg/L as $\mathrm{N})$ & $<.010$ & $<.010$ \\
\hline Dissolved phosphorus (mg/L as $\mathrm{P}$ & $<.050$ & $<.050$ \\
\hline Dissolved ortho-phosphorus (mg/L as $\mathrm{P}$ ) & $<.010$ & $<.010$ \\
\hline Total phosphorus (mg/L as $\mathrm{P}$ ) & $<.050$ & $<.050$ \\
\hline Dissolved arsenic ( $\mu \mathrm{g} / \mathrm{L}$ as As) & 1.1 & $<1.0$ \\
\hline Dissolved barium $(\mu \mathrm{g} / \mathrm{L}$ as $\mathrm{Ba})$ & 62 & $<1$ \\
\hline Dissolved beryllium ( $\mu \mathrm{g} / \mathrm{L}$ as $\mathrm{Be})$ & $<2$ & $<2$ \\
\hline Dissolved boron ( $\mu \mathrm{g} / \mathrm{L}$ as $\mathrm{B})$ & 314 & $<16$ \\
\hline Dissolved iron $(\mu \mathrm{g} / \mathrm{L}$ as $\mathrm{Fe})$ & $<10$ & $<10$ \\
\hline Dissolved manganese ( $\mu \mathrm{g} / \mathrm{L}$ as $\mathrm{Mn})$ & 3 & $<2$ \\
\hline Dissolved mercury $(\mu \mathrm{g} / \mathrm{L}$ as $\mathrm{Hg}$ ) & $<.1$ & $<.1$ \\
\hline Dissolved zinc $(\mu \mathrm{g} / \mathrm{L}$ as $\mathrm{Zn})$ & E11 & $<20$ \\
\hline
\end{tabular}


Table S-4. Percent difference between concentrations in field samples and replicate samples from well GW-4, Grand Portage Reservation, Minnesota, August 16, 1999

$\left[\mathrm{mg} / \mathrm{L}\right.$, milligrams per liter; $\mu \mathrm{g} / \mathrm{L}$, micrograms per liter; ${ }^{\circ} \mathrm{C}$, degrees Celsius; <, less than; E, estimated; --, no data]

\begin{tabular}{|c|c|c|c|}
\hline Constituent & Field sample & Replicate & $\begin{array}{c}\text { Percent } \\
\text { difference }\end{array}$ \\
\hline $\mathrm{pH}$, whole water, laboratory (standard units) & 8.5 & 8.6 & -0.6 \\
\hline Specific conductance, laboratory $\left(\mu \mathrm{S} / \mathrm{cm}\right.$ at $\left.25^{\circ} \mathrm{C}\right)$ & 1700 & 1710 & -0.3 \\
\hline Dissolved calcium ( $\mathrm{mg} / \mathrm{L}$ as $\mathrm{Ca}$ ) & 65.9 & 68.4 & -1.8 \\
\hline Dissolved magnesium (mg/L as $\mathrm{Mg}$ ) & 0.58 & 0.6 & -1.7 \\
\hline Dissolved potassium (mg/L as $\mathrm{K})$ & 2.0 & 2.0 & 0 \\
\hline Dissolved sodium (mg/L as $\mathrm{Na})$ & 257 & 258 & -.2 \\
\hline Acid neutralizing capability, laboratory $\left(\mathrm{mg} / \mathrm{L}\right.$ as $\mathrm{CaCO}_{3}$ ) & 44 & 37 & 8.6 \\
\hline Dissolved chloride (mg/L as $\mathrm{Cl}$ ) & 453 & 452 & .1 \\
\hline Dissolved fluoride (mg/L as F) & 1.2 & 1.3 & -4 \\
\hline Dissolved silica $\left(\mathrm{mg} / \mathrm{L}\right.$ as $\left.\mathrm{SiO}_{2}\right)$ & 22.3 & 22.2 & .2 \\
\hline Dissolved sulfate $\left(\mathrm{mg} / \mathrm{L}\right.$ as $\left.\mathrm{SO}_{4}\right)$ & 58.2 & 58.6 & -.3 \\
\hline Total ammonia plus organic nitrogen $(\mathrm{mg} / \mathrm{L}$ as $\mathrm{N})$ & 0.21 & 0.1 & 35.5 \\
\hline Dissolved ammonia nitrogen (mg/L as $\mathrm{N}$ ) & $<.020$ & $<.020$ & -- \\
\hline Dissolved nitrite plus nitrate nitrogen $(\mathrm{mg} / \mathrm{L}$ as $\mathrm{N})$ & $<.050$ & $<.050$ & -- \\
\hline Dissolved nitrite nitrogen $(\mathrm{mg} / \mathrm{L}$ as $\mathrm{N})$ & $<.010$ & $<.010$ & -- \\
\hline Dissolved phosphorus (mg/L as $\mathrm{P}$ ) & $<.050$ & $<.050$ & -- \\
\hline Dissolved ortho-phosphorus (mg/L as $\mathrm{P}$ ) & $<.010$ & $<.010$ & -- \\
\hline Total phosphorus (mg/L as $\mathrm{P})$ & $<.050$ & $<.050$ & -- \\
\hline Dissolved aluminum $(\mu \mathrm{g} / \mathrm{L}$ as $\mathrm{Al})$ & -- & -- & -- \\
\hline Dissolved arsenic ( $\mu \mathrm{g} / \mathrm{L}$ as As) & $<1.0$ & 1.1 & -- \\
\hline Dissolved barium $(\mu \mathrm{g} / \mathrm{L}$ as $\mathrm{Ba})$ & 61 & 62 & -.8 \\
\hline Dissolved beryllium ( $\mu \mathrm{g} / \mathrm{L}$ as $\mathrm{Be})$ & $<2$ & $<2$ & -- \\
\hline Dissolved boron $(\mu \mathrm{g} / \mathrm{L}$ as $\mathrm{B})$ & 305 & 314 & -1.5 \\
\hline Dissolved iron $(\mu \mathrm{g} / \mathrm{L}$ as $\mathrm{Fe})$ & $<10$ & $<10$ & -- \\
\hline Dissolved manganese ( $\mu \mathrm{g} / \mathrm{L}$ as $\mathrm{Mn})$ & 3 & 3 & 0 \\
\hline Dissolved mercury $(\mu \mathrm{g} / \mathrm{L}$ as $\mathrm{Hg})$ & $<.1$ & $<.1$ & -- \\
\hline Dissolved selenium ( $\mu \mathrm{g} / \mathrm{L}$ as $\mathrm{Se})$ & $<1.0$ & -- & -- \\
\hline Dissolved silver $(\mu \mathrm{g} / \mathrm{L}$ as $\mathrm{Ag})$ & $<1$ & -- & -- \\
\hline Dissolved zinc $(\mu \mathrm{g} / \mathrm{L}$ as $\mathrm{Zn})$ & 14 & E11 & 12 \\
\hline
\end{tabular}

